\title{
How membranes shape plant symbioses: signaling and transport in nodulation and arbuscular mycorrhiza
}

\author{
Laure Bapaume and Didier Reinhardt* \\ Department of Biology, University of Fribourg, Fribourg, Switzerland
}

\section{Edited by:}

Markus Geisler, University of

Fribourg, Switzerland

\section{Reviewed by:}

Daniel Wipf, Burgundy University,

France

Soizic Rochange, Toulouse

University, France

*Correspondence:

Didier Reinhardt, Department of Biology, University of Fribourg, Rte Albert Gockel 3, CH-1700 Fribourg, Switzerland.

e-mail: didier.reinhardt@unifr.ch
As sessile organisms that cannot evade adverse environmental conditions, plants have evolved various adaptive strategies to cope with environmental stresses. One of the most successful adaptations is the formation of symbiotic associations with beneficial microbes. In these mutualistic interactions the partners exchange essential nutrients and improve their resistance to biotic and abiotic stresses. In arbuscular mycorrhiza (AM) and in root nodule symbiosis (RNS), AM fungi and rhizobia, respectively, penetrate roots and accommodate within the cells of the plant host. In these endosymbiotic associations, both partners keep their plasma membranes intact and use them to control the bidirectional exchange of signaling molecules and nutrients. Intracellular accommodation requires the exchange of symbiotic signals and the reprogramming of both interacting partners. This involves fundamental changes at the level of gene expression and of the cytoskeleton, as well as of organelles such as plastids, endoplasmic reticulum (ER), and the central vacuole. Symbiotic cells are highly compartmentalized and have a complex membrane system specialized for the diverse functions in molecular communication and nutrient exchange. Here, we discuss the roles of the different cellular membrane systems and their symbiosis-related proteins in AM and RNS, and we review recent progress in the analysis of membrane proteins involved in endosymbiosis.

Keywords: symbiosis, arbuscule, mycorrhiza, LysM receptor, SYMRK, VAPYRIN, root nodules, rhizobium

\section{INTRODUCTION}

In nature, the majority of plants live in association with fungal and/or bacterial symbionts. The most widespread symbiosis in all taxa of extant land plants is arbuscular mycorrhiza (AM). The fossil record and phylogenetic analysis suggest an early origin of AM before the Devonian period, approximately $450 \mathrm{Ma}$ ago (Redecker et al., 2000; Heckman et al., 2001; Kistner and Parniske, 2002). AM occurs between fungi of the phylum Glomeromycota, also referred to as AM fungi, and the majority of land plants in almost all ecological niches (Wang and Qiu, 2006), and is thought to be essential for plant survival in harsh environments such as deserts and hot springs (Bunn et al., 2009; Al-Yahya'ei et al., 2011). Whereas AM fungi can colonize the majority of land plants, root nodule symbiosis (RNS) with bacteria (rhizobia), which has evolved considerably later than AM (Kistner and Parniske, 2002), involves almost exclusively legumes (Fabaceae).

\footnotetext{
Abbreviations: AM, Arbuscular mycorrhiza; CCaMK, Calcium and calmodulindependent protein kinase; DMI, Does not make infections; ER, Endoplasmic reticulum; IT, Infection thread; LCO, Lipochitooligosaccharide; LRR, Leucine-rich repeat; LYK, LysM-containing receptor-like kinase; LYM, LysM-containing protein; LysM, Lysin motif; MAPK, Mitogen-activated protein kinase; MF, Myc factor, mycorrhization factor; MFR, Myc factor receptor; NCR, Nodule-specific cysteinerich; NF, Nod factor, nodulation factor; NFR, Nod factor receptor; NPC, Nuclear pore complex; PAM, Periarbuscular membrane; PIT, Pre-infection thread; PPA, Prepenetration apparatus; PT, Phosphate transporter; RNS, Root nodule symbiosis; SNARE, soluble $\mathrm{N}$-ethylmaleimide-sensitive factor attachment protein receptor; SPC, Signal peptidase complex; SYMRK, Symbiosis receptor kinase; SYP, Syntaxin of plants; VAMP, Vesicle-associated membrane protein.
}

AM and RNS are both regulated by a common set of genes that define the common SYM pathway. They encode a receptor kinase localized to the plasma membrane, components of signal transduction to the nucleus, and a nuclear CCaMK (calcium and calmodulin-dependent protein kinase; Parniske, 2008; Oldroyd et al., 2011; Singh and Parniske, 2012).

Upon detection of AM fungal hyphopodia, epidermal cells generate an infection structure, the prepenetration apparatus (PPA) that is essential for infection of epidermal cells (Genre et al., 2005, 2008). At later stages of AM, finely branched hyphal structures, the arbuscules, are formed by AM fungi which serve to increase the surface area for nutrient exchange. In RNS, root hair cells form a curl in which bacteria are entrapped and subsequently guided through an infection thread (IT) toward the root cortex (Fournier et al., 2008). Cortical cells prepare for infection with a pre-infection thread (PIT) before they come into contact with the rhizobia (Van Brussel et al., 1992). Ultimately, in the mature nodules, bacteria differentiate into bacteroids inside the cytoplasm of the host (Jones et al., 2007; Oldroyd et al., 2011).

The arbuscules and bacteroids are contained within hostderived membranes that represent specialized symbiotic interfaces dedicated to nutrient exchange (Spaink, 1995; Limpens et al., 2005; Parniske, 2008). As a consequence of the large contact area between the host and the endosymbiont, the membrane surface area of host cells (comprising plasma membrane and the membrane around the endosymbiont) increases several-fold during arbuscule formation (Cox and Sanders, 1974), and up to 
20-fold in the case of nodule cells filled with nitrogen-fixing bacteria (Verma et al., 1978). Similarly, the endomembrane system undergoes a general expansion since the amount of organelles such as ER, plastids, and mitochondria is amplified (Genre et al., 2005; Lohse et al., 2005; Fournier et al., 2008; Genre et al., 2008; Figures 1 and 2). These adaptations during the transition of a cortical cell to an active symbiotic machinery requires the production of large amounts of new membrane material in the host, and of specialized membrane proteins for symbiotic communication and nutrient exchange.

While the components involved in recognition and signal transduction are expressed constitutively, the machinery required for the functioning of endosymbioses is induced as a consequence of the transcriptional reprogramming of the symbiotic host cells. Many of these genes, which encode among others transporters of various mineral nutrients, are expressed only in symbiotic cells and are therefore likely to play symbiosis-specific roles. In the case of AM, the plant receives nutrients such as phosphorus $(\mathrm{P})$, nitrogen $(\mathrm{N})$, sulfur $(\mathrm{S})$, zinc $(\mathrm{Zn})$, and copper $(\mathrm{Cu})$, which are taken up by the periarbuscular membrane (PAM) in arbusculecontaining cells (Clark and Zeto, 2000; Karandashov and Bucher, 2005; Allen and Shachar-Hill, 2009; Tian et al., 2010; Smith and Smith, 2011), whereas in RNS, the plant is provided with N only (Prell and Poole, 2006). In exchange plants provide carbohydrates (C) to their symbionts (Prell and Poole, 2006; Smith and Smith, 2011). Consistent with a central role of membranes in symbiosis, a large part of the symbiosis-related proteins are localized to membranes. Here, we discuss the different roles of membrane

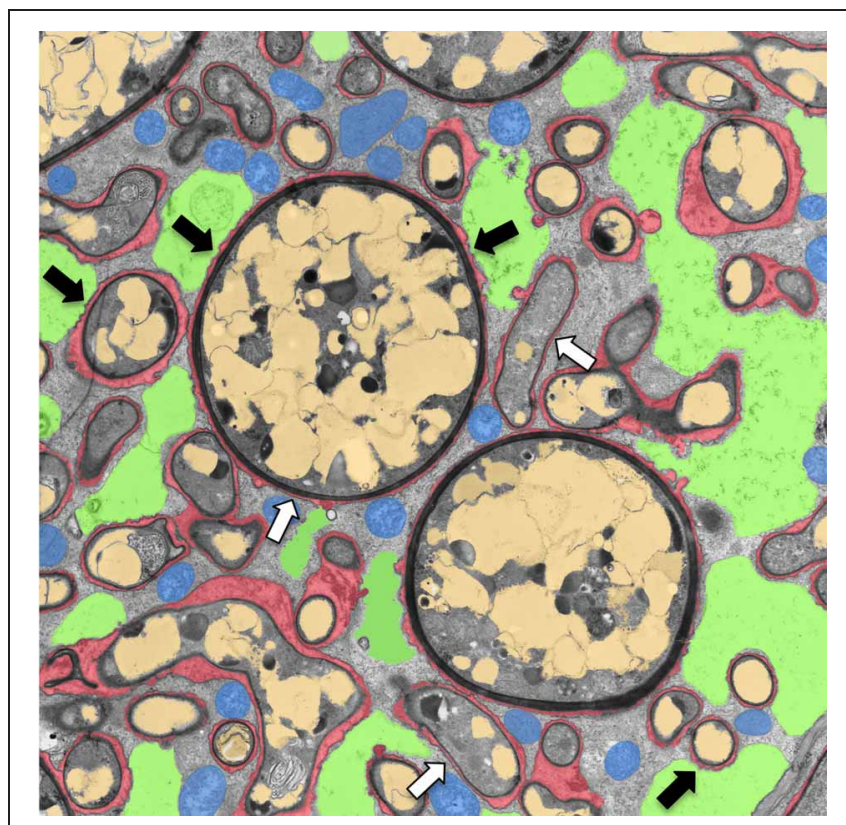

FIGURE 1 | Transmission electron micrograph of a cortical cell of P hybrida colonized by $\boldsymbol{G}$. intraradices (Rhizophagus irregularis). For clarity, cellular components are pseudocolored as follows: green, fragmented plant vacuole; blue, plant mitochondria and plastids; light brown, fungal vacuoles; red, symbiotic interface. Note the very close contact of the periarbuscular membrane (PAM) with fungal hyphae (white arrows), and the proximity of the tonoplast with the PAM (black arrows). systems in endosymbiosis and we review recent progress in the analysis of symbiosis-related proteins on membranes and their roles in signaling, intracellular accommodation, and nutrient transport.

\section{SYMBIOTIC SIGNALING}

\section{FLAVONOIDS, STRIGOLACTONES, NOD FACTORS, AND MYC FACTORS}

The rhizosphere is a habitat for a plethora of microbes (Pini et al., 2012). Most of them are neutral commensalists, but some are relevant for plants, either as pathogens or as mutualists. Since it is vital for the plant to react early and adequately, communication in the rhizosphere is crucial for plant survival. Most plant species constitutively release from their roots diffusible signal molecules, strigolactones that stimulate hyphal branching in AM fungi (Akiyama et al., 2005; Besserer et al., 2006), as well as in fungal pathogens (Dor et al., 2011). However, whereas AM fungal metabolism is stimulated by strigolactones (Besserer et al., 2006), the growth of fungal pathogens is inhibited (Dor et al., 2011).

Strigolactone is secreted from roots of petunia (Petunia hybrida) by the ATP-binding cassette subtype G (ABCG) transporter PDR1 (Kretzschmar et al., 2012; Figure 3). PDR1 is expressed preferentially during $\mathrm{P}$ starvation, a condition that favors AM. PDR1 is localized to the plasma membrane of the subepidermal passage cells, which are the preferred entry point for AM fungi (Sharda and Koide, 2008). Hence, PDR1 may play a role in establishing strigolactone gradients that direct AM fungal hyphae toward suitable points for root penetration (Kretzschmar et al., 2012).

The roots of legumes secrete flavonoids that are perceived as diffusible attractants by rhizobia and that activate them to produce a specific symbiotic signal, the nod factor (NF; Hassan

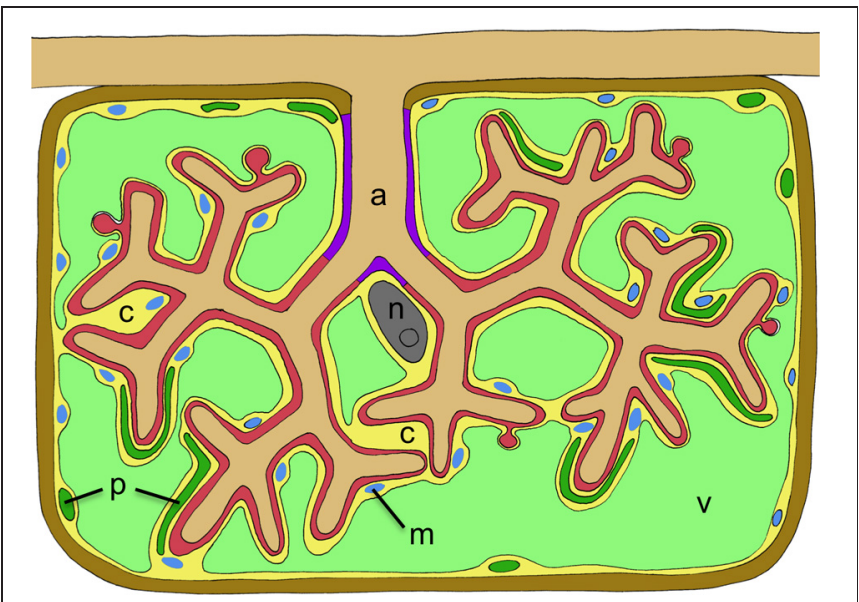

FIGURE 2 | Schematic representation of a cortex cell with an arbuscule. The arbuscule takes most of the space that is normally occupied by the central vacuole. Cellular compartments are colored in light green (plant vacuole), dark green (plant plastids), blue (plant mitochondria), yellow (plant cytoplasm), gray (nucleus), red (symbiotic interface), purple (trunc portion of the symbiotic interface), and brown (plant cell wall). The cellular constituents of the host are marked with letters as follows: c, cytoplasm; $m$, mitochondria; $n$, nucleus; $p$, plastids; $v$, vacuole. The fungal arbuscule is marked as well (a). 


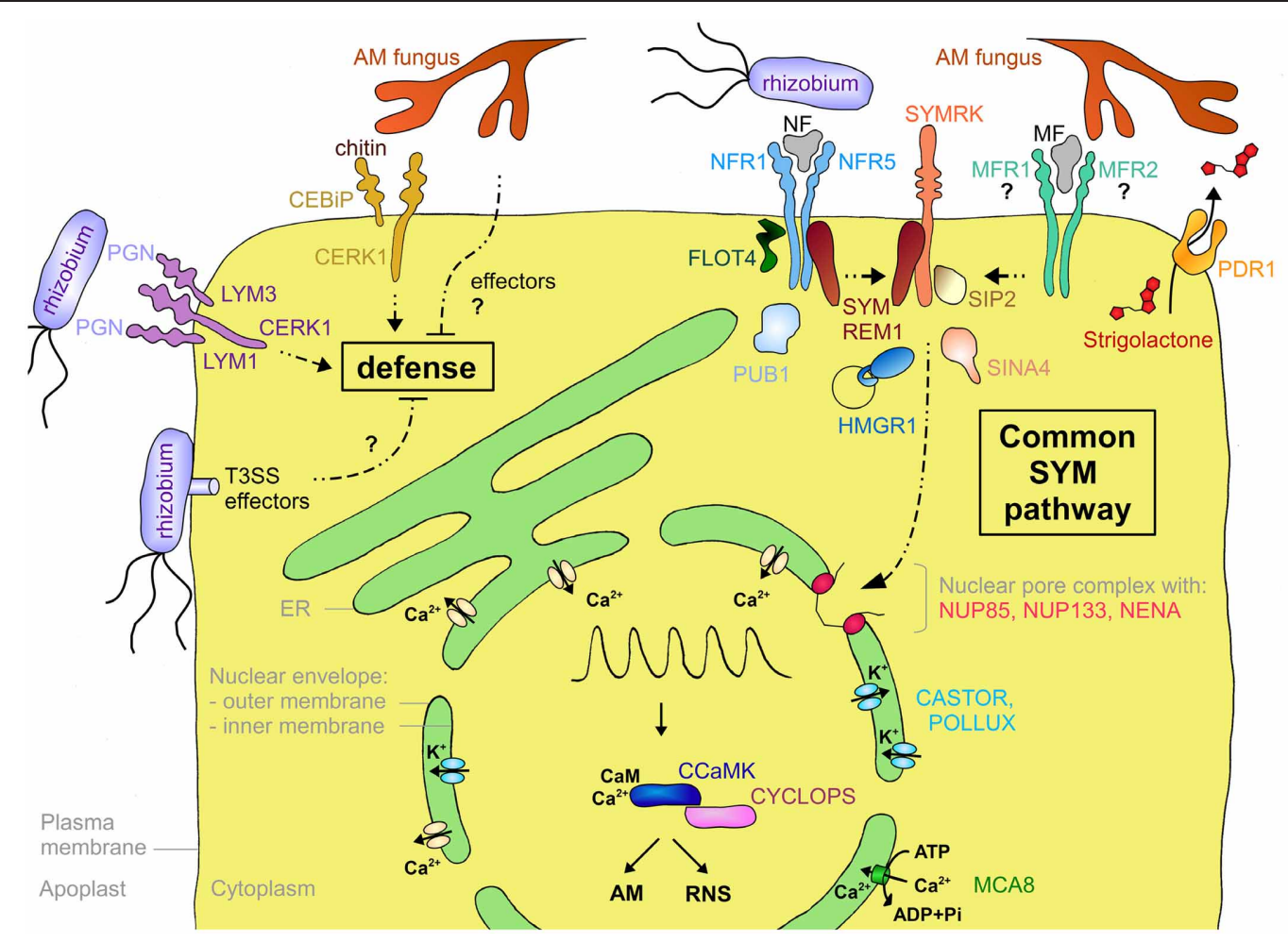

FIGURE 3 | Schematic representation of a plant cell with the major components involved in symbiotic signaling and defense signaling. The central vacuole has been omitted for clarity. Solid arrows indicate transport fluxes whereas dashed arrows represent signaling pathways. Receptor complexes involving LysM proteins originate from different plant species. Perception of bacterial peptidoglycan (PGN) is represented by CERK1, LYM1, and LYM3 of Arabidopsis. Chitin perception is represented by rice proteins CERK1 and CEBiP. The nod factor receptors (NFR1 and NFR5) are from L. japonicus, whereas the elusive nature of the myc factor receptors (MFR1 and MFR2) is shown with question marks. The common SYM pathway is represented by SYMRK, NENA, NUP85, NUP133, CASTOR, POLLUX, CCAMK, and CYCLOPS from L. japonicus. The remaining components (MCA8, SIP2, FLOT4, PUB1, SYMREM1, SINA4, and HMGR1) were described in $M$. truncatula or L. japonicus, except for PDR1 that was discovered in petunia. See Table A1 and the main text for more information on the respective genes and their function in symbiosis. and Mathesius, 2012). NFs are lipochitooligosaccharides (LCOs) that induce early plant responses such as root hair curling (Gough and Cullimore, 2011) and nodule organogenesis.

Only recently, LCO signal molecules similar to NFs were isolated from AM fungi, referred to as myc factors (MF; Maillet et al., 2011), indicating that AM and RNS involve similar symbiotic signals. In view of the obvious similarities in signaling between AM and RNS, it is still a mystery why RNS is characterized by a distinct host-specificity and very narrow host ranges (Wang et al., 2012), whereas AM exhibit a very low degree of specificity, resulting in extremely large host ranges (Smith and Read, 2008).

\section{LysM RECEPTORS}

Legumes have dedicated NF receptors (NFRs) that are localized to the plasma membrane and consist of an extracellular domain with two to three lysin motif (LysM) repeats and an intracellular kinase domain (Madsen et al., 2003; Radutoiu et al., 2003; Arrighi et al., 2006; Lohmann et al., 2010). LysM repeats were first identified in bacterial enzymes where they are involved in the binding of peptidoglycans (Buist et al., 2008). LysM-containing receptorlike kinases (LYKs) are plant-specific and occur as families of 5-21 members per species (Zhang et al., 2009). NF perception requires two LysM-containing proteins, which may function as dimers like many eukaryotic receptor systems (Gough and Cullimore, 2011; Gust et al., 2012; Figure 3). In Lotus japonicus they are referred to as Nod factor receptor1 (NFR1) and NFR5 (Madsen et al., 2003; Radutoiu et al., 2003), whereas in Medicago truncatula they are referred to as LYK3 and Nod factor perception (NFP), respectively (Ben Amor et al., 2003; Smit et al., 2007). Interestingly, the members of one of the subfamilies (including NFR5 and NFP) have a non-functional kinase domain, consistent with the idea that they may form a signaling complex with a second receptor that contains a functional kinase domain (Madsen et al., 2011). Domain swapping experiments between different NFRs and mutation analysis of the extracellular LysM domain support the idea that this part of the receptor (in particular LysM repeat 2) may be involved in the recognition of NFs (Radutoiu et al., 2007; Bensmihen et al., 2011). Indeed, NFR1 and NFR5 were recently shown to bind NF, presumably with their glycosylated extracellular LysM domain (Broghammer et al., 2012).

LCOs have an $N$-acetylglucosamine backbone (Dénarié et al., 1996) that they share with chitin and peptidoglycan (Lovering et al., 2012), the major components of fungal and bacterial cell walls, respectively. Plants have very sensitive receptors for 
chitin and peptidoglycan oligomers that are structurally related to NFRs (Figure 3). In rice (Oryza sativa), two LysM-containing proteins, CEBiP (chitin oligosaccharide elicitor-binding protein) and CERK1 (chitin elicitor receptor kinase1), interact to form a chitin receptor at the plasma membrane (Kaku et al., 2006; Shimizu et al., 2010). In Arabidopsis, CERK1 which contributes to resistance against fungal pathogens, and LYM2 (LysM-containing protein2), a close homolog of CEBiP, can bind chitin (Miya et al., 2007; Wan et al., 2008; Petutschnig et al., 2010). However, recent mutant analysis suggests that despite its chitin-binding activity LYM2 is dispensable for chitin signaling (Shinya et al., 2012). Indeed, CERK1 alone, in particular its LysM repeat 2, can bind chitin oligomers and dimerize to form a functional receptor (Liu et al., 2012). Nevertheless, another LysM protein, LYK4, contributes to chitin signaling (Wan et al., 2012). Interestingly, CERK1 of Arabidopsis could also form a trimeric receptor complex with LYM1 and LYM3 that recognizes bacterial peptidoglycan. The binding activity is attributed to LYM1 and LYM3, whereas CERK1 appears to be responsible for subsequent defense signaling (Gimenez-Ibanez et al., 2009; Willmann et al., 2011). These results suggest that in general LysM-containing receptors may be formed by combinatorial oligomerization of different LYKs and LYMs (Figure 3). Notably, despite its inability to engage in symbiosis, Arabidopsis can perceive NFs at nanomolar concentrations (Khan et al., 2011), indicating that chitin or peptidoglycan receptors may have an affinity for LCOs. The fact that AM-competent plants such as rice (see above), and M. truncatula (Fliegmann et al., 2011) have chitin receptors raises the question how AM fungi escape defense response (see below).

While the NFRs of legumes recognize only one or few NFs, thereby limiting the host range in RNS (Wang et al., 2012), an NFP homolog of the non-legume Parasponia andersonii (Cannabaceae) serves as a common receptor in AM and RNS (Op Den Camp et al., 2011), suggesting that in this case the receptor can recognize different NFs and MFs. These results indicate that AM and RNS may have originally depended on the same receptor(s), which later diversified to produce functionally separate receptors for MFs and NFs in legumes. The functional characterization of further MF receptors (MFRs) from non-legume species will help understand the evolution and function of the LYKs.

\section{SYMRK}

A central component of symbiotic signaling is the symbiosis receptor-like kinase SYMRK that is essential for both AM and RNS (Figure 3). SYMRK was initially identified in Medicago sativa and L. japonicus (Endre et al., 2002; Stracke et al., 2002) but later was found to be conserved in most angiosperms. SYMRKs from different symbiosis-competent species in different families can complement each other indicating that SYMRK is functionally conserved and does not contribute to host specificity in RNS (Gherbi et al., 2008; Markmann et al., 2008). Indeed, SYMRK is considered to be the first component of the common SYM pathway which presumably integrates intermediary signals resulting from perception of MF and NF at the plasma membrane (Parniske, 2008).

In addition to its role in AM and in RNS of legumes, SYMRK is also involved in the actinorrhizal nodule symbiosis of Casuarina glauca (Fagales) and Datisca glomerata (Cucurbitales) with actinobacteria of the genus Frankia (Gherbi et al., 2008; Markmann et al., 2008). Hence, SYMRK can be considered the central symbiotic entry point of endosymbioses in plants. Interestingly, SYMRK occurs in different forms, which define its symbiotic potential. All nodulating species, including legumes, D. glomerata, alder (Alnus glutinosa), as well as the non-nodulating species poplar (Populus trichocarpa) and Tropaeolum majus, have a long version of SYMRK with a long N-terminal extracellular region (NEC domain) and three leucine-rich repeat (LRR) motifs (Markmann et al., 2008). Non-nodulating species such as tomato (Solanum lycopersicum) and poppy (Papaver rhoeas), have a slightly shorter version with only two LRR motifs, while in the monocots, SYMRK lacks the entire NEC domain and has two LRR motifs (Markmann et al., 2008). Interestingly, only the full length SYMRK of nodulating plant species among the eurosids can fully complement nodulation in the L. japonicus symrk mutant, whereas the two shorter types of SYMRK complement only AM but not RNS. Surprisingly, full length SYMRK of the non-nodulating Tropaeolum was able to restore nodulation in L. japonicus (Markmann et al., 2008). This indicates that the longest version of SYMRK has gained the potential to induce bacterial accommodation in the AM-competent common ancestor of all nodulating plants, and that this ability led to the independent evolution of bacterial endosymbioses in several clades of the eurosids, whereas others (e.g., Tropaeolum), remained only AM-competent. Based on sequence comparison, the predisposition to bacterial symbiosis may be related to the third LRR motif in the full-length SYMRK.

\section{PROTEINS ASSOCIATED WITH SYMBIOTIC SIGNALING COMPONENTS AT THE PLASMA MEMBRANE}

In order to better understand the biochemical function of the receptors in symbiotic signaling, interacting protein partners have been searched for. A yeast two-hybrid screen with SYMRK yielded a MAPKK (mitogen-activated protein kinase kinase) termed SIP2, for SYMRK-interacting protein2 (Chen et al., 2012; Figure 3), which is conserved at least between L. japonicus and M. truncatula (Chen et al., 2012). MAPKKs are components of MAP kinase cascades, which are well known signal transduction pathways in plant-pathogen interactions (Tena et al., 2011). SIP2 is necessary for nodulation and may be subject to negative regulation from SYMRK in L. japonicus (Chen et al., 2012), indicating that fine-tuning of the MAPK cascade may be required for successful symbiosis.

Another interactor of SYMRK is the E3 ubiquitin ligase SINA4, Seven in absentia4 (Den Herder et al., 2012; Figure 3). SINA4 recruits SYMRK to small puncta at the plasma membrane that may represent microdomains dedicated to symbiotic signaling (see below). SINA4 negatively regulates SYMRK abundance and consequently modulates symbiosis signaling. In agreement with this notion, overexpression of SINA4 leads to defects in rhizobial infection (Den Herder et al., 2012). The NFR of M. truncatula LYK3 interacts with PUB1 (Plant U-box E3 ubiquitin ligase1), another type of E3 ligase induced during RNS (Mbengue et al., 2010; Figure 3). LYK3, which is involved in NF selectivity (Smit 
et al., 2007), can phosphorylate PUB1, which in turn acts as a negative regulator of LYK3 function in infection and nodulation (Mbengue et al., 2010). Hence, PUB1 may indirectly modulate symbiosis signaling.

Interaction with several symbiosis-related receptor kinases was recently shown for remorins, a plant-specific gene family, of which at least one member, SYMREM1, is involved in nodulation (Jarsch and Ott, 2011). SYMREM1 interacts with the symbiosis receptor kinases NFP, LYK3, and DMI2 (Does not make infections2) in M. truncatula (Lefebvre et al., 2010), and with their respective orthologs in L. japonicus NFR5, NFR1, and SYMRK (Toth et al., 2012) (Figure 3). SYMREM1 is strongly and specifically upregulated in nodules and localizes to ITs, in particular at their tips where unwalled infection droplets form, and in symbiosomes (Lefebvre et al., 2010; Toth et al., 2012).

In M. truncatula an isoform of the isoprenoid biosynthetic enzyme HMGR (3-hydroxy-3-methylglutaryl coenzyme A reductase) was identified as an interactor of SYMRK (Kevei et al., 2007; Figure 3). Only one member of the HMGR gene family (HMGR1) interacted with SYMRK, demonstrating the specificity of the interaction. Reduction of HMGR1 activity, either by RNA interference or pharmacological inhibition of the enzyme, resulted in a strong reduction of nodulation. HMGR activity is involved in the biosynthesis of sterols, terpenoids, and in particular cytokinin, which plays an important role in RNS (Oldroyd et al., 2011). HMGR1 has two membrane-spanning domains and it localizes to small intracellular compartments of unknown identity (Kevei et al., 2007). It remains to be shown how HMGR1 interacts with SYMRK, which is localized to the plasma membrane, and what its role in nodulation is.

\section{MEMBRANE MICRODOMAINS AS SIGNALING PLATFORMS IN SYMBIOSIS?}

The plasma membrane of eukaryotes has long been thought to consist of fluid lipid bilayers in which proteins freely diffuse laterally like soluble molecules in a two-dimensional solution (Singer and Nicolson, 1972). However, biophysical as well as cell biological studies revealed that the plasma membrane is not homogeneous, but instead contains microdomains with sizes in the range of $10-100 \mathrm{~nm}$ in diameter that are different in their lipid and protein composition from the surrounding membrane. These microdomains are rich in sphingolipids and sterols and form platforms that can move laterally along the plasma membrane, a feature for which they were termed "lipid rafts" (Simons and Ikonen, 1997). Lipid rafts contain proteins involved in cellular signaling and membrane trafficking, whereas other general plasma membrane proteins are excluded from them. A large part of the "lipid raft" literature is based on fractionation of detergentresistant membrane material, a technique that has been criticized for its potential to produce artifactual results (Tanner et al., 2011). We therefore focus here on proteins of which the localization has been confirmed in vivo with fluorescent markers or with transmission electron microscopy using immunogold labeling and we use the more generic term "microdomain" instead of "lipid rafts."

One of the first microdomain protein markers identified in plants is remorin (Jarsch and Ott, 2011). Remorins lack a transmembrane domain or membrane anchor, hence their localization to IT and symbiosome membranes is likely to result from binding to integral membrane proteins such as LysM receptors and SYMRK (see above). The co-localization of SYMREM1 with these receptor kinases (Lefebvre et al., 2010; Toth et al., 2012) indicates that either SYMREM1 localization is a consequence of the receptors being concentrated in microdomains, or that it is involved in recruiting these receptors to microdomains, although such a mechanism has not been directly documented by fluorescently tagged proteins as in the case of SINA4 (Den Herder et al., 2012).

Recently, flotillins have been implicated in RNS (Haney and Long, 2010; Haney et al., 2011) (Figure 3). Flotillins are well conserved proteins in animals and plants (Banning et al., 2011), and like remorins, they have no membrane spanning domain, but they localize to the plasma membrane, and they are concentrated in microdomains. In M. truncatula, which has a flotillin gene family of seven members, FLOT2 and FLOT4 are required for RNS (Haney and Long, 2010). Inoculation of M. truncatula with rhizobia favors co-localization of FLOT4 with LYK3 in microdomains of root hairs (Haney et al., 2011). In analogy to their function in animal systems, plant flotillins may function by bringing together in microdomains components of NF signaling, thereby increasing the efficiency and perhaps the specificity of symbiosis signaling at the membrane.

Taken together, NFRs and SYMRK, together with SYMREM1, FLOT4, and SINA4, could occur primarily in membrane microdomains that serve as dedicated signaling platforms at the plasma membrane (Simon-Plas et al., 2011). The observation that down-regulation of the membrane steroid-binding protein MSBP1 in M. truncatula interferes with AM (Kuhn et al., 2010), indicates that regulation of sterol homeostasis may be important for AM. Given the fact that microdomains are enriched in sterols, MSBP1 could affect AM by interfering with microdomain assembly. Interestingly, signaling platforms on membrane microdomains are involved not only in symbiosis, but also in plant-pathogen interactions (Bhat et al., 2005; Keinath et al., 2010). In addition, recent evidence suggests that membrane microdomains are also involved in sugar transport (Doidy et al., 2012).

\section{INTRACELLULAR CALCIUM SIGNALING AT PERINUCLEAR MEMBRANES}

Besides the plasma membrane proteins involved in symbiont recognition and early signal transduction (see above), membrane proteins with essential functions in symbiosis are localized to the nuclear envelope and the ER (Figure 3). The central second messenger in symbiosis is a rhythmic calcium transient (calcium spiking) that triggers transcriptional reprogramming in host cells (Oldroyd and Downie, 2006). Calcium spiking occurs around the nucleus, suggesting that the responsible calcium channels are localized to the membrane of the nuclear envelope, and that the calcium derives from the nuclear envelope (Capoen et al., 2011). Several components of the nuclear pore complex (NPC) are required for symbiotic signaling (Parniske, 2008). Mutations in the nucleoporins (NUPs) NUP85, NUP133, and NENA lead to defective calcium spiking and aborted symbiosis (Kanamori 
et al., 2006; Saito et al., 2007; Groth et al., 2010). Although their role in symbiosis remains elusive, one possibility is that NUPs are involved in the translocation of membrane proteins between the inner and the outer membrane of the nuclear envelope.

The common SYM pathway also involves cation channels, DMI1 in M. truncatula and its homologs in L. japonicus, CASTOR and POLLUX, which all localize to the nuclear envelope (Riely et al., 2007; Charpentier et al., 2008; Parniske, 2008). These cation channels are thought to mediate potassium fluxes to compensate the charge imbalance resulting from calcium fluxes (Peiter et al., 2007; Charpentier et al., 2008). While the calcium channels that release the calcium are elusive, a calcium ATPase of M. truncatula (MCA8) has recently been described as an essential component in calcium spiking, presumably involved in reloading the calcium into the lumen of the nuclear envelope (and the ER), thereby replenishing its stores and resetting the low resting concentration of calcium in the cytoplasm and nucleoplasm (Capoen et al., 2011).

The specific calcium signatures in AM (Kosuta et al., 2008; Chabaud et al., 2011) and RNS (Oldroyd and Downie, 2006) are thought to be decoded by CCaMK (Oldroyd and Downie, 2006; Singh and Parniske, 2012). Activation of downstream transcriptional programs requires interaction with, and phosphorylation of, the CCaMK substrate CYCLOPS (Yano et al., 2008; Horvath et al., 2011). The orthologue of CYCLOPS, IPD3 (Interacting Protein of DMI3), is required for symbiosis in M. truncatula, rice and pea (Pisum sativum), respectively (Messinese et al., 2007; Chen et al., 2008; Horvath et al., 2011; Ovchinnikova et al., 2011).

\section{EVOLUTION OF SYMBIOTIC SIGNALING}

Based on the fossil record and on the widespread occurrence of $\mathrm{AM}$ among the majority of vascular plants, the origin of AM is likely to have predated the radiation of land plants (Kistner and Parniske, 2002). It is conceivable that AM may even have been a precondition for successful colonization of land (Brundrett, 2002), although AM may not have been the earliest mycorrhizal association of land plants (Bidartondo et al., 2011). The finding that the common SYM genes are functionally conserved among mono- and dicotyledonous plant species (Chen et al., 2007, 2008; Gutjahr et al., 2008, 2012), and that they occur in lower plants such as liverworts, hornworts, mosses, and lycophytes has proven their ancient origin (Wang et al., 2010a). Interestingly, non-mycorrhizal angiosperms such as Arabidopsis have lost most common SYM genes, whereas the moss Physcomitrella patens has retained homologs of all SYM genes analyzed (Wang et al., 2010a), despite its apparent inability to undergo endosymbiosis (Wang and Qiu, 2006; Ligrone et al., 2012). It remains to be seen whether the common SYM genes of mosses play a role in other fungal associations, or whether the SYM pathway may serve other functions in the life of mosses.

Based on the fact that a number of genes are commonly required for both, AM and RNS, and that RNS ooccurs only in few taxa of the angiosperms, it was concluded that RNS evolved less than $100 \mathrm{Ma}$ ago in an angiosperm predecessor that was already competent to engage in AM (Kistner and Parniske, 2002). Considering the different nodulation types, it is interesting to note that the common SYM genes are conserved also in species that form actinorhizal symbiosis (e.g., A. glutinosa, C. glauca) (Hocher et al., 2011), supporting the view that actinorrhizal symbiosis may have evolved independently from RNS in legumes, but from a common ancestor that became predisposed for bacterial symbiosis (Soltis et al., 1995; Pawlowski and Demchenko, 2012), perhaps by the modification of the LRR domain of SYMRK (Markmann et al., 2008) (see above).

The similarities between NFs and MFs (Maillet et al., 2011), and their receptors (Op Den Camp et al., 2011), also argue for a common evolutionary root of AM and RNS. In addition, the close homology of NFRs with the chitin receptor CERK1 indicates that the recognition of symbionts and pathogens derive from a common ancestral perception mechanism (Zhang et al., 2009). Since chitin, peptidoglycans and NF/MF share a common basic structure, the $N$-acetylglucosamine backbone, and since they are all perceived by LysM receptors, it is conceivable that recognition of symbiotic signals has evolved from a recognition mechanisms for an unspecific microbial signal such as chitin. The diversification of symbiotic signaling may then have been fostered by coevolution of NFRs with NFs during the evolution of RNS (Aguilar et al., 2004; Martinez-Romero, 2009). Interestingly, NFR1 and CERK1 are still so close that a few amino acid substitutions in the kinase domain of CERK1 are sufficient to confer to it the ability to induce nodules, when fused to the extracellular NF-binding domain of NFR1 (Nakagawa et al., 2011).

\section{HOW SYMBIONTS AND PATHOGENS INFLUENCE THEIR PERCEPTION IN PLANTS}

An open question is still why infection by AM fungi does not elicit a defense response in roots. Symbiotic plants retain, besides their NFRs and MFRs, potent receptors for microbial cell wall constituents such as chitin and peptidoglycan oligomers, which can trigger defense responses (Shimizu et al., 2010; Willmann et al., 2011). Hence, given the fact that AM fungal cell walls consist mainly of chitin, the perception of chitin fragments by plants could be expected to trigger a defense response that could block symbiosis. Indeed, some defense markers show a small transient induction at early stages of AM (García-Garrido and Ocampo, 2002), indicating that general microbe-associated molecular patterns (MAMPs) from AM fungi are perceived and elicit a transient defense response, which later is suppressed. Suppression may result from symbiotic signaling downstream of NFRs and MFRs or from manipulation by the AM fungus.

In order to escape a defense response, many microbes, beneficial and pathogenic, have evolved tools to interfere with their recognition either by hiding or by interfering with the deployment of a defense response (Zamioudis and Pieterse, 2012). The fungal pathogen Cladosporium fulvum has found a particularly elegant way to use the chitin-binding LysM motif to avoid its recognition: it secretes large amounts of a LysM-containing protein (Ecp6) that binds to soluble chitin fragments, thereby sequestering them from detection by the chitin receptors of the plant (Bolton et al., 2008; De Jonge et al., 2010). Hence Ecp6 is an effector protein that prevents detection of the pathogen by the host, and therefore contributes to virulence of the pathogen. Recently, an effector of an AM fungus has been described that is taken up by the host and functions through modification of defense-related 
gene expression in the nucleus (Kloppholz et al., 2011). It remains to be seen whether AM fungi have also tools to directly interfere with the perception of MAMPs such as chitin. Bacterial pathogens produce their own effectors to interfere with LysM receptor function, thereby preventing their detection (Gimenez-Ibanez et al., 2009; Zeng et al., 2012). Bacterial effectors are in many cases delivered directly into the cytoplasm of the host by the type-three secretion system that also exists in rhizobia (Kambara et al., 2009). Interestingly, rhizobia contain homologs of pathogen effectors that influence infectivity and host range in RNS (Lewis et al., 2011; Soto et al., 2011).

\section{INFECTION AND INTRACELLULAR ACCOMMODATION INITIAL ACCOMMODATION: INFECTION THREAD AND PREPENETRATION APPARATUS}

Intracellular accommodation of the microbial partner is the central unifying aspect of endosymbioses. In order to keep the invaded host cells intact, the microbial endosymbiont has to remain separated from the host cytoplasm by a host-derived membrane, which also has the role to control the environment of the microbe and to retrieve nutrients from it. Thus, endosymbioses require reorganization of the entire cell, in particular of the membrane system.

In order for rhizobia to invade root hair cells, the cell wall has to become locally softened and permeable. This implies a reduction in turgor pressure to avoid the plasma membrane of the host cell to rupture at the entry point. In addition, the invagination of the plasma membrane is likely to require a lowering of the turgor pressure, because the rhizobia cannot exert any inward force to promote invagination. On their way through the root hair cell, rhizobia are guided through the IT, a tubular hollow structure in which the bacteria remain confined and start to multiply. Toward the center of the root and below infected root hairs, files of cortical cells prepare for bacterial infection, before the rhizobia reach them, implying long distance transmission of a symbiotic signal (Oldroyd and Downie, 2008). Preparation of cortical cells involves migration of the nuclei to the cell center and formation of a cytoplasmic bridge through the central vacuole that traces the route for the formation of the IT, as in root hairs. This structure composed of cytoplasm and endomembranes has been termed the PIT (Van Brussel et al., 1992). On its centripetal path, the nucleus heads the PIT machinery which consists of large amounts of cytoplasm with ER thought to produce the elements of the IT (Fournier et al., 2008). Elements of the microtubular cytoskeleton are involved in the formation of the IT as well (Timmers et al., 1998). The absence of bacteria from the growing tip of the IT suggests that it is formed by the host without a direct contribution of rhizobia, although continuous signaling from the bacteria (e.g., trough NF) may influence IT development (Timmers et al., 1998; Fournier et al., 2008).

When epidermal cells are in contact with AM fungi, a similar process is triggered which consists of nuclear migration toward the contact point and assembly of an infection structure referred to as PPA. The PPA consists of dense cytoplasm with large amounts of ER cisternae, Golgi stacks, trans-Golgi network, and multivesicular bodies (Genre et al., 2005, 2008). These features of the PPA signify a strong biosynthetic activity, possibly associated with the invagination of the plasma membrane, in which the fungus inserts upon penetration of the cell wall. In dmi2 and dmi3 mutants, the nucleus of epidermal cells travels toward the fungal hyphopodium, but PPA formation does not occur (Genre et al., 2005), indicating that it is after nuclear migration and before PPA assembly that symbiotic signaling occurs.

\section{GENERATION OF SYMBIOTIC MEMBRANE SYSTEMS}

The generation of the host-derived membranes associated with PIT, IT, and PPA requires de novo synthesis of new membrane material and of membrane proteins with specific symbiosisrelated functions in signaling and transport. Intense vesicular trafficking has indeed been observed at the growing tip of ITs (Robertson and Lyttleton, 1982). Likewise, infecting hyphae of AM fungi are surrounded by dense cytoplasm with ER, numerous Golgi stacks, vesicles, and other markers of exocytotic activity (Genre et al., 2008, 2012). Finally, the formation of the arbuscules in AM and the multiplication of the bacteroids in RNS, respectively, is associated with the massive expansion of the surfaces of the PAM and of the collective symbiosome membranes (Box 1). These observations demonstrate the need for intense membrane

\section{Box 1 | What is the Identity of the Periarbuscular and the Symbiosome Membranes?}

At the first intracellular stages of AM and RNS, the microbes are surrounded by the invaginated plasma membrane, and in the case of AM and some legume species that host the bacteria in fixation threads (Naisbitt et al., 1992), the PAM and the peribacteroid membrane remain continuous with the plasma membrane. The symbiosomes of most legumes, however, are isolated entities like organelles in the cytoplasm, and could therefore be compared topologically with vesicles or little vacuoles, rather than with the plasma membrane. Indeed, symbiosomes exhibit several common features with prevacuolar compartments that could turn into, or fuse with, lytic vacuoles to digest their content (Mellor, 1989). Interestingly, the analysis of membrane markers revealed an intermediate identity of the symbiosome membrane. The specific localization of the M. truncatula syntaxin MtSYP132 to symbiosome membranes signifies plasma membrane identity, indicating that the bacteroids reside in an "intracellular apoplastic domain" (Catalano et al., 2004, 2007; Limpens et al., 2009). Thereafter, the symbiosome membrane also carries Rab7, a marker for late endosomal/early vacuolar identity. This indicates that the symbiosome membrane goes through a phase of chimeric identity between plasma membrane and vacuolar identity (Limpens et al., 2009). At the onset of senescence, the appearance of the SNARE markers SYP22 and VTI11 signifies the identity of a lytic vacuole, in which the bacteroids are digested (Limpens et al., 2009). It is concluded that active symbiosomes are locked in a state of prevacuolar identity with contributions of plasmalemma identity. Considering the numerous symbiosis-specific features of symbiosome membrane and PAM, e.g., symbiosis-specific nutrient transporters (see main text), they may have a third, new identity which partially overlaps with plasma membrane and tonoplast identity. In addition, the PAM is subdivided into an arbuscule trunk region and the fine branches (Figure 2), which are characterized by different marker proteins (Pumplin and Harrison, 2009). 
biosynthesis and trafficking during infection and endosymbiont accommodation.

Membrane trafficking proceeds through vesicles that are fused with target membranes by a highly conserved protein machinery (Pratelli et al., 2004; Jahn and Scheller, 2006). Central players in vesicular trafficking are the SNAREs (soluble $N$-ethylmaleimidesensitive factor attachment protein receptors), of which there are two main types: R-SNAREs (also referred to as VAMP for vesicle-associated membrane proteins) on vesicle membranes and Q-SNAREs (some called syntaxins) on target membranes such as plasma membrane or tonoplast.

\section{VESICLE TRAFFICKING TO HOST-DERIVED PERIMICROBIAL MEMBRANES}

Intense cellular trafficking occurs in both mutualistic and pathogenic plant-microbe interactions (Wang and Dong, 2011; Yun and Kwon, 2012). It contributes to the local supply of new membrane material or to the delivery of cargo material (proteins or secondary metabolites) to the site of the interaction. A genetic screen in Arabidopsis identified PEN1/SYP121 (PENETRATION1/Syntaxin of plants121), a syntaxin with a specific role in plant immunity (Collins et al., 2003). PEN1 forms a SNARE complex with SNAP33 (Soluble $N$-ethylmaleimidesensitive factor Adaptor Protein 33), VAMP721 and/or VAMP722, thereby providing an exocytotic delivery system for antifungal substances that contribute to full immunity in non-host resistance (Kwon et al., 2008). A related syntaxin of Nicotiana benthamiana (NbSYP132) plays a role in resistance against a bacterial pathogen, presumably by transporting antimicrobial proteins toward the site of bacterial infection (Kalde et al., 2007).

The symbiosome membranes of $M$. truncatula contain a syntaxin that is closely related to the aforementioned NbSYP132, namely MtSYP132 (Catalano et al., 2007). MtSYP132 may be involved in vesicle trafficking toward symbiosomes, however, the fact that it persists on the symbiosome membrane throughout its active period until senescence (Limpens et al., 2009) indicates that its function may reach beyond the generation of the symbiosome membrane, perhaps in the regulation of ion channels as it was shown for SYR1 (Syntaxin-related protein1) of Nicotiana tabacum (Leyman et al., 1999).

In $M$. truncatula, two vacuolar components of the quarternary SNARE complex, VAMP721d and VAMP721e, which are closely related to the PEN1 interactor VAMP721 of Arabidopsis (see above), play an essential role in intracellular accommodation of bacteroids and arbuscules (Ivanov et al., 2012). However, whether they interact with SYP132 on the symbiosome membrane, and what the cargo of the concerned vesicles might be, remains to be established. Taken together, these results show that in symbiosis as well as in pathogenesis of plants, a closely related machinery acts to either support intracellular accommodation of mutualistic microbes, or to fend off pathogens, respectively (Wang and Dong, 2011).

Recent evidence suggests that not all symbiosis-related factors delivered to the symbiotic interface through secretion rely on a symbiosis-specific trafficking pathway. Targeting of P transporters to the PAM may be independent of specific determinants of subcellular localization, and rather results from a general reorientation of protein trafficking from the plasma membrane toward the PAM (Pumplin et al., 2012). According to this scenario, localization to the PAM does not require specific targeting signals, but merely depends on the timing of gene expression.

\section{SECRETION TOWARD DEVELOPING BACTEROIDS}

Further evidence for a role of protein trafficking and secretion during RNS comes from the finding that the development of functional nodules requires the signal peptidase complex, SPC (Wang et al., 2010b). Secreted or integral membrane proteins have an N-terminal signal peptide that is recognized by a signal peptide recognition particle early during translation. The nascent protein together with the ribosome is then attached to the ER, so that the protein becomes inserted into the ER membrane or transported through it. Concomitantly, the signal peptide is removed by a signal peptidase, an essential step for further processing of the protein. The mutant defective in nitrogen fixation1 (dnf1) carries a mutation in the subunit SPC22 of the SPC. Although it is not the catalytic subunit, its homolog in yeast is essential for signal peptidase activity and cell growth (Fang et al., 1997). Surprisingly, dnf1 has no developmental phenotype (Starker et al., 2006), suggesting that the function of the SPC22 subunit in M. truncatula is symbiosis-specific. Dnf1 mutants accumulate nodule-specific cysteine-rich (NCR) peptides in the ER, instead of secreting them into symbiosomes, where they cause the terminal differentiation of bacteroids, a prerequisite for determinate nodule development (Van De Velde et al., 2010).

Bacteroids can differentiate in two ways which differ in their degree of determinacy. In L. japonicus, the bacteroids retain their morphology and reproductive capacity, i.e., they remain indeterminate, whereas in $M$. truncatula, they terminally differentiate, involving a large size increase and the inability to divide. The fate of bacteroids is thought to depend on the plant, as some rhizobia can adopt both fates in function of their host (Mergaert et al., 2006). Indeed, expression of M. truncatula NCR peptides in L. japonicus causes rhizobia to terminally differentiate (Van De Velde et al., 2010). NCR247 peptide can trigger terminal differentiation of Sinorhizobium meliloti also in vitro (Van De Velde et al., 2010). Interestingly, high concentrations of NCR247 peptide interfere with bacterial membrane integrity, thereby exerting antimicrobial activity. This effect is particularly pronounced toward bacA mutants of S. meliloti, revealing a protective effect of BacA against NCR peptides (Haag et al., 2011). As BacA is predicted to encode a cytoplasmic subunit of an $\mathrm{ABC}$ transporter, this protein could be involved in either the uptake or efflux of NCR peptides in order to prevent plasma membrane damage (Haag et al., 2011). BacA mutants are protected in the $d n f 1$ mutant because NCRs are retained in the ER. These results show that RNS does not represent perfect harmony but rather a balance between cooperation and control.

\section{ROLES OF ORGANELLES IN SYMBIOSIS}

Cells with arbuscules and symbiosomes generally contain large amounts of organelles, indicative of intense metabolic activity (Figures 1 and 2). The plastids in mycorrhizal cells are of particular interest because they are closely associated with the arbuscules, 
and they considerably change their shape to a network-like system, referred to as stromules (Lohse et al., 2005, 2006; Strack and Fester, 2006). The plastids of mycorrhizal roots are active in carotenoid and apocarotenoid metabolism, which may be significant for symbiosis due to their role in the biosynthesis of the hormones gibberellin, ABA and strigolactone (Walter et al., 2010). Furthermore, plastids serve as factories for fatty acid biosynthesis, which is a prerequisite for the expansion of the membrane systems in symbiotic cells.

During AM and RNS the large central vacuole of colonized cells fragments to yield room for the accommodation of the symbiont (Cox and Sanders, 1974; Bonfante-Fasolo, 1984; Van Brussel et al., 1992; Hause and Fester, 2005). The close association of the symbiosome membrane with the tonoplast in mycorrhizal cells (Figure 1) may indicate a role of vacuolar membranes or vacuolar constituents in symbiosis.

\section{A NEW CELLULAR COMPARTMENT INVOLVED IN SYMBIOSIS?}

In a genetic screen for mutants affected in intracellular accommodation of AM fungi in $P$. hybrida, the mutant penetration and arbuscule morphogenesis1 (pam1), was isolated (Sekhara Reddy et al., 2007). PAM1 encodes a novel plant-specific protein with an $\mathrm{N}$-terminal major sperm protein (MSP) domain that is also found in the VAMP-associated proteins (VAPs) which are involved in vesicle trafficking (Lev et al., 2008; Feddermann et al., 2010). The C-terminus consists of 11 ankyrin repeats (Feddermann and Reinhardt, 2011), which are involved in protein-protein interactions in eukaryotes (Bennett and Baines, 2001; Mosavi et al., 2004). Due to this domain structure, the protein is referred to as VAPYRIN. VAPYRIN homologs were found in almost all plant species, including the non-symbiotic moss $P$. patens, but with the notable exception of $A$. thaliana.
Functional conservation of VAPYRIN was shown in M. truncatula, where vapyrin mutants are defective in both AM and in RNS, indicating that intracellular accommodation, like the common SYM pathway, is shared between bacterial and fungal endosymbioses (Pumplin et al., 2010; Murray et al., 2011). The fact that calcium spiking is normal in vapyrin mutants shows that VAPYRIN acts downstream of the calcium signal and perhaps of the entire common SYM signaling pathway (Murray et al., 2011).

Petunia VAPYRIN localizes to the nucleus and the cytoplasm, with a conspicuous accumulation to mobile spherical structures that are associated with the tonoplast, and therefore termed tonospheres (Feddermann et al., 2010). In AM of petunia, tonospheres associate with fungal hyphae (Feddermann et al., 2010). In M. truncatula, mobile puncta with VAPYRIN-GFP protein that probably correspond to tonospheres, accumulate exclusively in colonized cells (Pumplin et al., 2010). VAPYRIN does not contain a signal peptide, nor any predicted transmembrane domain, indicating that the association with membranes is likely to result from protein-protein interaction with resident membrane proteins (Feddermann and Reinhardt, 2011).

\section{MEMBRANE TRANSPORTERS IN SYMBIOSIS}

The "raison d'être" of endosymbioses is the exchange of nutrients representing a mutual benefit to both symbiotic partners (Box 2). In RNS this involves primarily the transfer of $\mathrm{N}$ in the form of ammonium from bacteroids to the plant, and the reverse transfer of dicarboxylic acids such as malate, fumarate, or succinate to the bacteroids (Prell and Poole, 2006). In the case of AM, there is a range of nutrients that AM fungi can deliver to plants, with the most prominent examples of $\mathrm{P}, \mathrm{N}$, and $\mathrm{S}$ (Allen and ShacharHill, 2009; Smith and Smith, 2011). However, AM fungi can also

\section{Box 2 | Are Nutritional Fluxes between Plants and AM Fungi Interrelated?}

The ancient origin and the wide distribution of AM raises the question how mutualism has been stabilized over evolutionary time, but also during ontogenetic development. Mutualism requires a high degree of coordination and synchronization between the partners, and is prone to exploitation by one or the other, leading to a parasitic or pathogenic interaction. Indeed, heterotrophic (achlorophyllous) plants have in multiple independent cases turned into parasites of AM fungi (Merckx et al., 2012). In a less extreme converse scenario, an AM interaction can result in a negative growth effect on the plant reflecting a parasitic relationship where the costs of the interaction exceed the benefit for the plant (Li et al., 2008). However, in most cases, AM are mutualistic, and exploitation is the exception.

How is mutualism stabilized in AM? One possibility is that the partners prevent exploitation by imposing sanctions on their partner in case of reduced symbiotic service. There are indeed indications for such a scenario: for example, the flux of $P_{\mathbf{i}}$ toward the plant influences to which extent the fungus is allowed to proliferate in the root. If $P_{\mathbf{i}}$ delivery is blocked by a mutation in the PT of the plant, fungal colonization is reduced, and intracellular fungal structures are subject to premature senescence (Maeda et al., 2006; Javot et al., 2007). On the other end of the scale, high levels of $P_{\mathbf{i}}$ also repress AM fungal colonization (Breuillin et al., 2010). In both cases, the phenotype is different than in common SYM mutants, indicating that symbiosis is blocked at a rather late stage. However, high $P_{\mathbf{i}}$ supply is also known to impact on early signaling through the inhibition of strigolactone biosynthesis (Balzergue et al., 2011).

Direct insight into sanctions come from measurements of nutrient flux in monoxenic root cultures as a function of nutrient supply and environmental conditions. For example, plants can reduce $C$ allocation to $A M$ fungi, when they are supplied with optimal $P_{\mathbf{i}}$ levels through fertilization (Olsson et al., 2010). Conversely, when AM are supplied with limited $C$ levels, $P_{\mathbf{i}}$ accumulates in the AM fungus instead of being transferred to the plant (Hammer et al., 2011). However, the question arises, whether in a more natural setting, when plants and AM fungi occur simultaneously in combinations with several potential partners, plants and AM fungi can selectively identify and reward better mutualists. This question was tested in an elegant approach, where isotope incorporation into newly synthesized fungal RNA allowed the separation of material from different AM fungi hosted by the same plant, allowing to estimate their relative consumption of sugar from the plant (Kiers et al., 2011). These experiments directly showed that plants colonized by two AM fungi preferentially reward the fungus that provides more $P_{\mathbf{i}}$ (Kiers et al., 2011). Conversely, AM fungi allocate $P_{\mathbf{i}}$ and $N$ preferentially to roots that supply them with more $C$ (Fellbaum et al., 2011; Kiers et al., 2011). These results document that AM involve a bidirectional rewarding system which can be considered a "biological market" and which is believed to help maintain mutualism within individual AM interactions and over evolutionary times. 
acquire water and micronutrients from the soil and deliver them to the plant host in exchange for fixed C (Clark and Zeto, 2000).

\section{WATER RELATIONS AND AQUAPORINS}

AM fungi can increase the drought resistance of plants in several ways. Firstly, some AM fungi can considerably promote water uptake of mycorrhizal plants (Marulanda et al., 2003), and they can prevent leaf dehydration during drought and salt stress (Aroca et al., 2007). Furthermore, mycorrhizal plants have a lower and more stable root hydraulic conductance than nonmycorrhizal plants, leading to increased water use efficiency (WUE) that is higher amounts of photosynthate generated per volume of acquired water (Augé, 2001). Improved water relations may result from a generally improved nutritional status, but direct effects of AM fungi on water uptake and transport have also been reported (Marulanda et al., 2003; Egerton-Warburton et al., 2007).

In principle, water flux across membranes proceeds passively through osmosis along proteinaceous pores that facilitate water diffusion through the membrane (Zeuthen, 2010). Aquaporins facilitate water transfer through membranes along an osmotic gradient, but they cannot actively pump water against a water potential gradient. In plants, aquaporins occur as exceptionally large and diverse gene families, suggesting that they play important roles in various processes of plant life (Maurel et al., 2009; Anderberg et al., 2012). Aquaporins of higher plants are classified into five groups, according to their subcellular localization, expression pattern, and protein structure: plasma membrane intrinsic proteins (PIPs), tonoplast intrinsic proteins (TIPs), nodulin26-like intrinsic proteins (NIPs), small and basic intrinsic proteins (SIPs), and X intrinsic proteins (XIPs) (Danielson and Johanson, 2010).

Besides their function as water channels, aquaporins have been shown to facilitate the diffusion across membranes of low molecular weight neutral solutes such as glycerol, ammonia, and carbon dioxide (Dean et al., 1999; Uehlein et al., 2008; Hwang et al., 2010). Consistent with a role in endosymbiosis, several members of the PIP-, TIP-, and NIP-subfamilies are induced in both AM and RNS in rice, M. truncatula, L. japonicus, and petunia (Güimil et al., 2005; Hohnjec et al., 2005; Guether et al., 2009a; Breuillin et al., 2010). In particular the NIP NOD26, which can account for $10 \%$ of the total symbiosome membrane protein (Rivers et al., 1997; Catalano et al., 2004) is of considerable interest. With its ammonia transport activity, NOD26 would be well suited to allow for $\mathrm{N}$ transfer along the source to sink gradient between bacteroids and plant. The fact that NOD26 is also induced in AM (Güimil et al., 2005; Hohnjec et al., 2005; Guether et al., 2009a; Breuillin et al., 2010) is in line with the finding that AM fungi, like rhizobia, release $\mathrm{N}$ to the plant host in the form of ammonia (Govindarajulu et al., 2005). However, it should be noted that in the acidic environment of the symbiotic interface around arbuscules and bacteroids, ammonia is almost completely protonated to the charged form ammonium $\left(\mathrm{NH}_{4}^{+}, \mathrm{pKb}=9.25\right)$, for which permeability in NOD26 has not been shown. Hence N uptake from the symbiotic interface into the host cytoplasm is more likely to be mediated by ammonium transporters (see below) than by NOD26.
In addition to their transport activity, aquaporins can mediate close interactions of juxtaposed membranes for example in the lens of mammals (Engel et al., 2008). Vacuolar subcompartments with multiple membrane layers and high contents of $\gamma$ - and $\delta$-TIP were observed in Arabidopsis cotyledons (Saito et al., 2002). These structures are highly mobile and move along the inner surface of the tonoplast to which they remain attached. Similar mobile structures were identified in mycorrhizal roots, where they contain the VAPYRIN protein (see above). Despite a number of reports about the involvement of aquaporins in AM and RNS, their exact biochemical function in symbiosis, as in many processes of plant development, remains to be established (Hill et al., 2004).

\section{$\mathrm{H}^{+}$-ATPases}

In contrast to the aquaporins, mineral nutrient transporters require an active transport mechanism, since they often act against a concentration gradient. Most nutrient transporters in the plasma membrane use the energy of the proton electrochemical gradient generated by $\mathrm{H}^{+}$-ATPases. In the direct (non-symbiotic) nutrient uptake pathway, plants acquire nutrients from the soil, whereas in the indirect mycorrhizal pathway, nutrients are taken up from the periarbuscular space over the PAM. In both cases, transport is energized by proton gradients. $\mathrm{H}^{+}$-ATPases are induced in AM (Gianinazzi-Pearson et al., 2000; Krajinski et al., 2002) and are thought to contribute to the uptake of inorganic phosphate $\left(\mathrm{P}_{\mathrm{i}}\right)$ and other nutrients from the symbiotic interface by proton symport (Karandashov and Bucher, 2005). Indeed, the periarbuscular space is acidified (Guttenberger, 2000), an observation which is compatible with the localization of an ATPase activity at the PAM (Marx et al., 1982). Hence, to energize nutrient uptake from the symbiotic interface, plants generate a proton gradient (Ferrol et al., 2002) to which the mycorrhizal fungus may also contribute (Requena et al., 2003; Breuninger and Requena, 2004; Balestrini and Lanfranco, 2007; Ramos et al., 2009). An activity analogous to the $\mathrm{H}^{+}$-ATPase in the PAM was identified at the symbiosome membrane, which provides both the plant and the bacteroids with an electrochemical gradient for nutrient uptake from the peribacteroid space (Fedorova et al., 1999; Saalbach et al., 2002; Catalano et al., 2004).

\section{PHOSPHATE TRANSPORT}

The most thoroughly studied nutrient transport pathway in $\mathrm{AM}$ is the transport of $\mathrm{P}_{\mathrm{i}}$ (Karandashov and Bucher, 2005) which is taken up from the soil by fungal $\mathrm{P}_{\mathrm{i}}$ transporters (PTs) (Harrison and Van Buuren, 1995; Maldonado-Mendoza et al., 2001; Requena et al., 2003; Benedetto et al., 2005). Surprisingly, a PT of Glomus mossae (GmosPT) is expressed at similar levels in the extraradical and intraradical mycelium (Benedetto et al., 2005). Hence, the AM fungus could potentially control $P_{i}$ flux toward the plant by partial re-uptake of $\mathrm{P}_{\mathrm{i}}$ from the root (Benedetto et al., 2005; Balestrini et al., 2007). AM fungi store $\mathrm{P}_{\mathrm{i}}$ as polyphosphate in tubular vacuoles (Uetake et al., 2002; Kuga et al., 2008; Olsson et al., 2011). Polyphosphate is a linear $P_{i}$ polymer that can comprise thousands of $P_{i}$ residues. Polyphosphate 
as vacuolar storage form helps to keep $\mathrm{P}_{\mathrm{i}}$ levels in a physiological range in the fungal cytoplasm, and prevents osmotic effects. Furthermore, the low cytoplasmic concentration of free $\mathrm{P}_{i}$ favors further $\mathrm{P}_{\mathrm{i}}$ uptake from the soil. Polyphosphate is translocated in mobile vacuoles from the extraradical mycelium to the mycorrhizal roots (Maldonado-Mendoza et al., 2001; Hijikata et al., 2010), and released as free $\mathrm{P}_{\mathrm{i}}$ into the periarbuscular space, where it is taken up by plant PTs.

The best-characterized symbiotic PT of plants is the M. truncatula AM-specific low-affinity transporter MtPT4, which is localized exclusively to the PAM (Harrison et al., 2002). MtPT4 activity is required not only for improved shoot $\mathrm{P}_{\mathrm{i}}$ status, but also for sustained AM colonization of the root system (Javot et al., 2007). In mtpt4 mutants, arbuscules accumulate polyphosphate, indicative of an impairment of $\mathrm{P}_{\mathrm{i}}$ transfer, and they senesce prematurely. Thus plants can sense the quality of symbiotic service and sustain or terminate symbiosis, depending on the resulting benefit (Javot et al., 2007). Solanaceae such as tomato and petunia have three AM-responsive PT genes (PT3-PT5) among which PT4 is the only AM-specific one (Wegmüller et al., 2008; Nagy et al., 2009). This redundancy complicates functional analysis compared to M. truncatula. In mycorrhizal tomato roots, high levels of LePT3 and LePT4 were detected in arbuscule-containing cells (Balestrini et al., 2007). In potato, the related StPT3 gene is active in cells with arbuscules as with hyphal coils (Rausch et al., 2001; Karandashov et al., 2004), consistent with active $\mathrm{P}_{\mathrm{i}}$ uptake in colonized cells of both Arum- and Paris-type AM. Expression of the AM-specific low-affinity rice PT OsPT11 is correlated with the degree of G. intraradices colonization, as MtPT4 (Harrison et al., 2002; Paszkowski et al., 2002; Kobae and Hata, 2010). OsPT11, which was studied in both Arum-type and Paris-type mycorrhiza, localizes exclusively to the membrane around branched hyphae, but not at the plasma membrane neither around hyphal coils or hyphal trunks, a pattern similar to MtPT4 (Harrison et al., 2002; Pumplin and Harrison, 2009; Kobae and Hata, 2010). Hence, the expression pattern and the subcellular localization of AM-specific PTs in mono- and dicotyledonous plants reveals a conserved $\mathrm{P}_{\mathrm{i}}$ uptake pathway in colonized cells of Arum- and Paris-type AM.

Interestingly, symbiosis-related PTs of monocots [e.g., OsPT11 of rice and ZmPT6 of maize (Zea mais)] and dicots (e.g., MtPT4 of M. truncatula and LePT4 of tomato) share a common phylogenetic root with the PT families of the lower land plants $P$. patens and Selaginella moellendorffi, documenting their common ancestral origin relative to the more derived members of the constitutive $\mathrm{P}_{\mathrm{i}}$ uptake pathway in angiosperms (Paszkowski, pers. communication). A close evolutionary relationship among the symbiosis-specific PT is also documented by the conservation of their promoter sequences relative to related PTs that are induced by AM to a lesser degree, such as the PT3 lineage of the Solanaceae (Rausch et al., 2001; Chen et al., 2011).

\section{NITROGEN TRANSPORT}

AM fungi, like roots, can acquire $\mathrm{N}$ from the soil primarily as nitrate $\left(\mathrm{NO}_{3}^{-}\right)$or as ammonium $\left(\mathrm{NH}_{4}^{+}\right)$(Tian et al., 2010), although organic forms may also be involved (Cappellazzo et al., 2008). Two ammonium transporters, GintAMT1 and GinAMT2, were identified in Glomus intraradices. The high affinity transporter GintAMT1 is substrate-inducible and is expressed preferentially in the extraradical mycelium (Lopez-Pedrosa et al., 2006; Perez-Tienda et al., 2011), whereas GintAMT2 is preferentially expressed in the intraradical mycelium and is not substrateregulated (Perez-Tienda et al., 2011). Interestingly, GintAMT1 and GintAMT2 are both expressed in arbuscule-containing cells (Perez-Tienda et al., 2011), indicating that they may modulate the amount of delivered $\mathrm{N}$ by reuptake, as it has been proposed for $\mathrm{P}_{\mathrm{i}}$ transport (see above).

Once in the extraradical mycelium, $\mathrm{N}$ is thought to be translocated in the form of arginine which carries four $\mathrm{N}$ atoms per molecule and therefore represents a concentrated transport form of $\mathrm{N}$ (Govindarajulu et al., 2005). The fate of $\mathrm{N}$ from the soil to the plant through the AM fungus has been well described through the analysis of the enzymatic steps of ammonium assimilation, arginin biosynthesis in the extraradical hyphae, and arginine catabolism in intraradical hyphae (Govindarajulu et al., 2005; Tian et al., 2010). $\mathrm{N}$ is then thought to be transferred to the periarbuscular space in an inorganic form probably as ammonium, which can be taken up by the PAM via ammonium transporters such as LjAMT2.2 in L. japonicus (Guether et al., 2009b), GmAMT4.1 in soybean (Glycine max) (Kobae et al., 2010), and their homologs in M. truncatula (Gomez et al., 2009; Gaude et al., 2012).

Like AM fungi, the bacteroids in nodules release fixed $\mathrm{N}$ in the form of ammonia which is taken up by ammonium transporters in the symbiosome membrane (Kaiser et al., 1998; Rogato et al., 2008). Whether the ammonia-permeable aquaporin NOD26 plays a prominent role in $\mathrm{N}$ uptake of plants, as suggested by Hwang et al. (2010) is not clear (see above). However, patch clamp experiments have revealed a channel-like activity through which ammonium from the peribacteroid space can be taken up into the cytoplasm of the host (Tyerman et al., 1995; Kaiser et al., 1998).

\section{CARBOHYDRATE TRANSPORT}

Recent progress has significantly advanced our understanding of sugar transport within plants and in the interaction with beneficial and pathogenic microbes (Doidy et al., 2012). For nutrition of endosymbiotic microbes, two sugar transport steps are required. First, symbiotic tissues such as nodules and mycorrhizal roots need to attract photosynthate in competition with other sinks, and they need to take up sugar either directly from the phloem, or from the surrounding apoplast. Secondly, symbiotic cells need to release an appropriate form of $\mathrm{C}$ to the microbe at the symbiotic interface. In plants, the mobile form of reduced $\mathrm{C}$ is primarily sucrose which is cleaved to hexoses (glucose and fructose) in sink tissues. Hence, sink tissues of plants can acquire carbohydrate either by sucrose transporters or by monosaccharide (hexose) transporters. Candidates for sink-related transporters in symbiosis are the AM-inducible hexose transporter Mtst1 in M. truncatula (Harrison, 1996), and the sucrose transporter LjSUT4 induced during nodule development in L. japonicus (Flemetakis et al., 2003).

It has long been an open question how hexoses may be released from cells in general, and from AM colonized cortex cells in particular. Only recently, a family of plant hexose transporters has been identified (SWEET) that can serve for hexose export from cells (Chen et al., 2010). SWEETs are uniporters that can transfer 
hexoses in both directions, depending on the sugar gradient over the plasma membrane. In animals, SWEETs release hexoses to extracellular compartments such as the blood (Chen et al., 2010). A. thaliana has 17 SWEETs, suggesting that they play diverse roles in plant life. SWEETs can be exploited by pathogens for their own nutrition (Chen et al., 2010). Interestingly, the nodule-specific MtN3 is a member of the M. truncatula SWEET family, and may therefore be involved in the nutrition of the bacteroids in nodules. Whether members of the SWEET family indeed play a role in AM or RNS remains to be shown.

Hexoses are the likely transfer form to supply the heterotrophic AM fungus with fixed C (Pfeffer et al., 1999). AM fungi have a hexose transporter, MST2, that can take up glucose, galactose, mannose and the oxidized sugars glucuronic and galacturonic acid (Helber et al., 2011). MST2 is required for fungal proliferation in roots, indicating that it is involved in nutrition of the fungus during symbiosis (Helber et al., 2011).

The C source provided to bacteroids in nodules consists of dicarboxylic acids (Long, 1989). Indeed, S. meliloti possesses a dicarboxylate transporter, DctA, which is suggested to transport several compounds, mainly malate and fumarate (Yurgel and Kahn, 2005). DctA is required for RNS, in particular for the energy-demanding $\mathrm{N}$ fixation by bacteroids, since $d c t A$ mutants are impaired in $\mathrm{N}$ fixation.

\section{OTHER TRANSPORTERS WITH POTENTIAL ROLES IN SYMBIOSIS}

Some proteins are required for the establishment of a functional endosymbiosis, but their cellular and biochemical function remains elusive. For instance the $L$. japonicus mutant $\operatorname{sen} 1$ can form nodules when colonized with Mesorhizobium loti, but the nodules remain pale and small, and $\mathrm{N}$ fixation is abolished (Hakoyama et al., 2012). SEN1, which is expressed specifically in the infected cells of nodules, is homologous to vacuolar cation transporters for iron and manganese. It is conceivable that a depletion in iron or manganese may hamper $\mathrm{N}$ fixation in bacteroids since iron is required for the nitrogenase complex, apart from general bacteroid metabolism (Hakoyama et al., 2012).

In AM, a likely candidate for a sulfate transporter was recently identified in M. truncatula (Casieri et al., 2012), however, its functional relevance in symbiosis, as well as its subcellular localization remain to be established. Two half-size $A B C$ transporters of the same species, STUNTED ARBUSCULE (MtSTR) and MtSTR2 are essential for functional arbuscules (Zhang et al., 2010). MtSTR and MtSTR2 are expressed specifically in arbuscule-containing

\section{REFERENCES}

Aguilar, O. M., Rival, O., and Peltzer, E. (2004). Analysis of Rhizobium etli and of its symbiosis with wild Phaseolus vulgaris supports coevolution in centers of host diversification. Proc. Natl. Acad. Sci. U.S.A. 101, 13548-13553.

Akiyama, K., Matsuzaki, K., and Hayashi, H. (2005). Plant sesquiterpenes induce hyphal branching in arbuscular mycorrhizal fungi. Nature 435, 824-827.
Allen, J. W., and Shachar-Hill, Y. (2009). Sulfur transfer through an arbuscular mycorrhiza. Plant Physiol. 149, 549-560.

Al-Yahya'ei, M., Oehl, F., Vallino, M., Lumini, E., Redecker, D., Wiemken, A., et al. (2011). Unique arbuscular mycorrhizal fungal communities uncovered in date palm plantations and surrounding desert habitats of Southern Arabia. Mycorrhiza 21, 195-209.

Anderberg, H. I., Kjellbom, P., and Johanson, U. (2012). Annotation

cells, where they localize to the PAM. MtSTR and MtSTR2 were found to heterodimerize creating a full-size transporter that is localized to the PAM around young and mature arbuscules, but not around the hyphal trunk. Homologs of MtSTR and MtSTR2 were found in rice (OsSTR1 and OsSTR2; Gutjahr et al., 2012), but not in the non-symbiotic model species A. thaliana, consistent with a specific role in symbiosis. However, their function in symbiosis remains elusive since their substrates are unknown.

\section{CONCLUSIONS}

Membranes are a central feature of life, since they allow the interior of cells to establish controlled conditions separated from the environment to provide optimal conditions for biochemical processes. In endosymbiosis, this aspect is accentuated, since two organisms cooperate in such close proximity that not much more than a membrane, a thin cell wall, and some interstitial material separates their cytoplasms. Therefore, highly organized membrane systems are at the core of endosymbioses. They are involved at all levels from initial recognition over intracellular accommodation to the establishment of the symbiotic interface, over which nutrients are exchanged. A topic that will attract increasing interest in coming years is the compartmentalization of the plasma membrane and the peri-microbial membranes (PAM and symbiosome membrane). An emerging scenario is that plants-like animals-have membrane microdomains that serve as signaling platforms in symbiosis and in plant-pathogen interactions. These membrane microdomains contain receptors and signaling components that are subject to dynamic regulation in space and time. Also, the emerging notion that the recognition of microbial pathogens and symbionts by LysM-containing receptors may share a common origin from non-self recognition mechanisms line out exciting new avenues for future research. Comparison of the molecular basis of symbiotic signaling and development in different taxa will help elucidate the evolution of AM in the ancestors of vascular plants, and the multiple emergence of RNS in a predisposed monophyletic clade within the angiosperms.

\section{ACKNOWLEDGMENTS}

We thank Eva Nouri for helpful discussion and support in the preparation of the manuscript. Our work is supported by the Swiss National Science Foundation (No. 31003A_135778/1) and by the National Centre of Competence in Research (NCCR) "Plant Survival."

of Selaginella moellendorffii major intrinsic protein and the evolution of the protein family in terrestrial plants. Front. Plant Sci. 3, 1-14.

Aroca, R., Porcel, R., and Ruiz-Lozano, J. M. (2007). How does arbuscular mycorrhizal symbiosis regulate root hydraulic properties and plasma membrane aquaporins in Phaseolus vulgaris under drought, cold or salinity stresses? New Phytol. 173, 808-816.

Arrighi, J. F., Barre, A., Ben Amor, B., Bersoult, A., Soriano, L. C.
Mirabella, R., et al. (2006). The Medicago truncatula lysine motifreceptor-like kinase gene family includes NFP and new noduleexpressed genes. Plant Physiol. 142, 265-279.

Augé, R. M. (2001). Water relations, drought and vesicular-arbuscular mycorrhizal symbiosis. Mycorrhiza 11, 3-42.

Balestrini, R., Gomez-Ariza, J., Lanfranco, L., and Bonfante, P. (2007). Laser microdissection reveals that transcripts for five 
plant and one fungal phosphate transporter genes are contemporaneously present in arbusculated cells. Mol. Plant Microbe Interact. 20, 1055-1062.

Balestrini, R., and Lanfranco, L. (2007). Fungal and plant gene expression in arbuscular mycorrhizal symbiosis (vol 16, pg 509, 2006). Mycorrhiza $17,153$.

Balzergue, C., Puech-Pagès, V., Bécard, G., and Rochange, S. F. (2011). The regulation of arbuscular mycorrhizal symbiosis by phosphate in pea involves early and systemic signalling events. J. Exp. Bot. 62, 1049-1060.

Banning, A., Tomasovic, A., and Tikkanen, R. (2011). Functional aspects of membrane association of Reggie/Flotillin proteins. Curr. Protein Pept. Sci. 12, 725-735.

Ben Amor, B., Shaw, S. L., Oldroyd, G. E. D., Maillet, F., Penmetsa, R. V., Cook, D., et al. (2003). The NFP locus of Medicago truncatula controls an early step of Nod factor signal transduction upstream of a rapid calcium flux and root hair deformation. Plant J. 34, 495-506.

Benedetto, A., Magurno, F., Bonfante, P., and Lanfranco, L. (2005). Expression profiles of a phosphate transporter gene (GmosPT) from the endomycorrhizal fungus Glomus mosseae. Mycorrhiza 15, 620-627.

Bennett, V., and Baines, A. J. (2001). Spectrin and ankyrin-based pathways: metazoan inventions for integrating cells into tissues. Physiol. Rev. 81, 1353-1392.

Bensmihen, S., De Billy, F., and Gough, C. (2011). Contribution of NFP LysM domains to the recognition of nod factors during the Medicago truncatula/Sinorhizobium meliloti symbiosis. PLoS ONE 6:e26114. doi: 10.1371/journal.pone.0026114

Besserer, A., Puech-Pagès, V., Kiefer, P., Gomez-Roldan, V., Jauneau, A., Roy, S., et al. (2006). Strigolactones stimulate arbuscular mycorrhizal fungi by activating mitochondria. PLoS Biol. 4:e226. doi: 10.1371/journal.pbio.0040226

Bhat, R. A., Miklis, M., Schmelzer, E., Schulze-Lefert, P., and Panstruga, R. (2005). Recruitment and interaction dynamics of plant penetration resistance components in a plasma membrane microdomain. Proc. Natl. Acad. Sci. U.S.A. 102, 3135-3140.

Bidartondo, M. I., Read, D. J., Trappe, J. M., Merckx, V., Ligrone, R., and Duckett, J. G. (2011). The dawn of symbiosis between plants and fungi. Biol. Lett. 7, 574-577.
Bolton, M. D., Van Esse, H. P., Vossen, J. H., De Jonge, R., Stergiopoulos, I., Stulemeijer, I. J. E., et al. (2008). The novel Cladosporium fulvum lysin motif effector Ecp6 is a virulence factor with orthologues in other fungal species. Mol. Microbiol. 69, 119-136.

Bonfante-Fasolo, P. (1984). "Anatomy and morphology of VA mycorrhizae," in VA Mycorrhizae, eds C. L. Powell and D. J. Bagyaraj (Boca Raton, FL, USA: CRC Press), 5-33.

Breuillin, F., Schramm, J., Hajirezaei, M., Ahkami, A., Favre, P., Druege, U., et al. (2010). Phosphate systemically inhibits development of arbuscular mycorrhiza in Petunia hybrida and represses genes involved in mycorrhizal functioning. Plant J. 64, 1002-1017.

Breuninger, $\mathrm{M}$., and Requena, $\mathrm{N}$. (2004). Recognition events in AM symbiosis: analysis of fungal gene expression at the early appressorium stage. Fungal Genet. Biol. 41, 794-804.

Broghammer, A., Krusell, L., Blaise, M., Sauer, J., Sullivan, J. T., Maolanon, N., et al. (2012). Legume receptors perceive the rhizobial lipochitin oligosaccharide signal molecules by direct binding. Proc. Natl. Acad. Sci. U.S.A. 109, 13859-13864.

Brundrett, M. C. (2002). Coevolution of roots and mycorrhizas of land plants. New Phytol. 154, 275-304.

Buist, G., Steen, A., Kok, J., and Kuipers, O. R. (2008). LysM, a widely distributed protein motif for binding to (peptido)glycans. Mol. Microbiol. 68, 838-847.

Bunn, R., Lekberg, Y., and Zabinski, C. (2009). Arbuscular mycorrhizal fungi ameliorate temperature stress in thermophilic plants. Ecology 90, 1378-1388.

Capoen, W., Sun, J., Wysham, D., Otegui, M. S., Venkateshwaran, M., Hirsch, S., et al. (2011). Nuclear membranes control symbiotic calcium signaling of legumes. Proc. Natl. Acad. Sci. U.S.A. 108, 14348-14353.

Cappellazzo, G., Lanfranco, L., Fitz, M., Wipf, D., and Bonfante, P. (2008). Characterization of an amino acid permease from the endomycorrhizal fungus Glomus mosseae. Plant Physiol. 147, 429-437.

Casieri, L., Gallardo, K., and Wipf, D. (2012). Transcriptional response of Medicago truncatula sulphate transporters to arbuscular mycorrhizal symbiosis with and without sulphur stress. Planta 235, 1431-1447.

Catalano, C. M., Czymmek, K. J., Gann, J. G., and Sherrier, D. J.
(2007). Medicago truncatula syntaxin SYP132 defines the symbiosome membrane and infection droplet membrane in root nodules. Planta 225, 541-550.

Catalano, C. M., Lane, W. S., and Sherrier, D. J. (2004). Biochemical characterization of symbiosome membrane proteins from Medicago truncatula root nodules. Electrophoresis 25, 519-531.

Chabaud, M., Genre, A., Sieberer, B. J., Faccio, A., Fournier, J., Novero, M., et al. (2011). Arbuscular mycorrhizal hyphopodia and germinated spore exudates trigger $\mathrm{Ca} 2+$ spiking in the legume and nonlegume root epidermis. New Phytol. 189, 347-355.

Charpentier, M., Bredemeier, R., Wanner, G., Takeda, N., Schleiff, E., and Parniske, M. (2008). Lotus japonicus CASTOR and POLLUX are ion channels essential for perinuclear calcium spiking in legume Root endosymbiosis. Plant Cell 20, 3467-3479.

Chen, A., Gu, M., Sun, S., Zhu, L., Hong, S., and $\mathrm{Xu}$, G. (2011). Identification of two conserved cis-acting elements, MYCS and $\mathrm{P} 1 \mathrm{BS}$, involved in the regulation of mycorrhiza-activated phosphate transporters in eudicot species. New Phytol. 189, 1157-1169.

Chen, C. Y., Ane, J. M., and Zhu, H. Y. (2008). OsIPD3, an ortholog of the Medicago truncatula DMI3 interacting protein IPD3, is required for mycorrhizal symbiosis in rice. New Phytol. 180, 311-315.

Chen, C. Y., Gao, M. Q., Liu, J. Y., and Zhu, H. Y. (2007). Fungal symbiosis in rice requires an ortholog of a legume common symbiosis gene encoding a $\mathrm{Ca} 2+/$ calmodulindependent protein kinase $(1[\mathrm{OA}])$. Plant Physiol. 145, 1619-1628.

Chen, L.-Q., Hou, B.-H., Lalonde, S., Takanaga, H., Hartung, M. L., Qu, X.-Q., et al. (2010). Sugar transporters for intercellular exchange and nutrition of pathogens. Nature $468,527-532$.

Chen, T., Zhu, H., Ke, D., Cai, K., Wang, C., Gou, H., et al. (2012). A MAP kinase kinase interacts with SymRK and regulates nodule organogenesis in Lotus japonicus. Plant Cell 24 823-838.

Clark, R. B., and Zeto, S. K. (2000), Mineral acquisition by arbuscular mycorrhizal plants. J. Plant Nutr. 23 , 867-902.

Collins, N. C., Thordal-Christensen, H., Lipka, V., Bau, S., Kombrink, E., Qiu, J. L., et al. (2003). SNAREprotein-mediated disease resistance at the plant cell wall. Nature 425 , 973-977.

Cox, G., and Sanders, F. (1974). Ultrastructure of the host-fungus interface in a vesicular-arbuscular mycorrhiza. New Phytol. 73, 901-912.

Danielson, J. A. H., and Johanson, U. (2010). "Phylogeny of major intrinsic proteins," in Mips and Their Role in the Exchange of Metalloids, eds T. P. Jahn and G. P. Bienert (New York, NY: Springer), 19-32.

De Jonge, R., Van Esse, H. P. Kombrink, A., Shinya, T., Desaki, Y., Bours, R., et al. (2010). Conserved fungal LysM effector Ecp6 prevents chitin-triggered immunity in plants. Science 329, 953-955.

Dean, R. M., Rivers, R. L., Zeidel, M. L., and Roberts, D. M. (1999). Purification and functional reconstitution of soybean nodulin 26. An aquaporin with water and glycerol transport properties. Biochemistry $38,347-353$.

Den Herder, G., Yoshida, S., AntolinLlovera, M., Ried, M. K., and Parniske, M. (2012). Lotus japonicus E3 ligase SEVEN IN ABSENTIA4 destabilizes the symbiosis receptorlike kinase SYMRK and negatively regulates rhizobial infection. Plant cell 24, 1691-1707.

Dénarié, J., Debellé, F., and Promé, J. C. (1996). Rhizobium lipochitooligosaccharide nodulation factors: signaling molecules mediating recognition and morphogenesis. Annu. Rev. Biochem. 65, 503-535.

Doidy, J., Grace, E., Kühn, C., SimonPlas, F., Casieri, L., and Wipf, D. (2012). Sugar transporters in plants and in their interactions with fungi. Trends Plant Sci. 17, 413-422.

Dor, E., Joel, D. M., Kapulnik, Y., Koltai, H., and Hershenhorn, J. (2011). The synthetic strigolactone GR24 influences the growth pattern of phytopathogenic fungi. Planta 234, 419-427.

Egerton-Warburton, L. M., Querejeta, J. I., and Allen, M. F. (2007). Common mycorrhizal networks provide a potential pathway for the transfer of hydraulically lifted water between plants. J. Exp. Bot. 58, 1473-1483.

Endre, G., Kereszt, A., Kevei, Z., Mihacea, S., Kaló, P., and Kiss, G. B. (2002). A receptor kinase gene regulating symbiotic nodule development. Nature 417, 962-966.

Engel, A., Fujiyoshi, Y., Gonen, T., and Walz, T. (2008). Junction-forming aquaporins. Curr. Opin. Struct. Biol. 18, 229-235. 
Fang, H., Mullins, C., and Green, N. (1997). In addition to SEC11, a newly identified gene, SPC3, is essential for signal peptidase activity in the yeast endoplasmic reticulum. J. Biol. Chem. 272, 13152-13158.

Feddermann, N., Duvvuru Muni, R. R., Zeier, T., Stuurman, J., Ercolin, F., Schorderet, M., et al. (2010). The $P A M 1$ gene of petunia, required for intracellular accommodation and morphogenesis of arbuscular mycorrhizal fungi, encodes a homologue of VAPYRIN. Plant J. 64, 470-481.

Feddermann, N., and Reinhardt, D. (2011). Conserved residues in the ankyrin domain of VAPYRIN indicate potential protein-protein interaction surfaces. Plant Signal. Behav. 6, 680-684.

Fedorova, E., Thomson, R., Whitehead, L. F., Maudoux, O., Udvardi, M. K., and Day, D. A. (1999). Localization of H+-ATPase in soybean root nodules. Planta 209, 25-32.

Fellbaum, C. R., Gachomo, E. W., Beesetty, Y., Choudhari, S., Strahan, G. D., Pfeffer, P. E., et al. (2011). Carbon availability triggers fungal nitrogen uptake and transport in arbuscular mycorrhizal symbiosis. Proc. Natl. Acad. Sci. U.S.A. 109, 2666-2671.

Ferrol, N., Gianinazzi, S., and Gianinazzi-Person, V. (2002). "Arbuscular mycorrhiza induced ATPases and membrane nutrient transport mechanisms," in Mycorrhizal Technology in Agriculture: from Genes to Bioproducts, eds S. Gianinazzi, H. Schüepp, J. M. Barea, and K. Haselwandter (Basel: Birkhäuser), 113-122.

Flemetakis, E., Dimou, M., Cotzur, D., Efrose, R. C., Aivalakis, G., Colebatch, G., et al. (2003). A sucrose transporter, LjSUT4, is upregulated during Lotus japonicus nodule development. J. Exp. Bot. 54, 1789-1791.

Fliegmann, J., Uhlenbroich, S., Shinya, T., Martinez, Y., Lefebvre, B., Shibuya, N., et al. (2011). Biochemical and phylogenetic analysis of CEBiP-like LysM domain-containing extracellular proteins in higher plants. Plant Physiol. Biochem. 49, 709-720.

Fournier, J., Timmers, A. C. J., Sieberer, B. J., Jauneau, A., Chabaud, M., and Barker, D. G. (2008). Mechanism of infection thread elongation in root hairs of Medicago truncatula and dynamic interplay with associated rhizobial colonization. Plant Physiol. 148, 1985-1995.
García-Garrido, J. M., and Ocampo, J. A. (2002). Regulation of the plant defence response in arbuscular mycorrhizal symbiosis. J. Exp. Bot. 53, 1377-1386.

Gaude, N., Bortfeld, S., Duensing, N., Lohse, M., and Krajinski, F. (2012). Arbuscule-containing and non-colonized cortical cells of mycorrhizal roots undergo extensive and specific reprogramming during arbuscular mycorrhizal development. Plant J. 69, 510-528.

Genre, A., Chabaud, M., Faccio, A., Barker, D. G., and Bonfante, P. (2008). Prepenetration apparatus assembly precedes and predicts the colonization patterns of arbuscular mycorrhizal fungi within the root cortex of both Medicago truncatula and Daucus carota. Plant Cell 20, 1407-1420.

Genre, A., Chabaud, M., Timmers, T., Bonfante, P., and Barker, D. G. (2005). Arbuscular mycorrhizal fungi elicit a novel intracellular apparatus in Medicago truncatula root epidermal cells before infection. Plant Cell 17, 3489-3499.

Genre, A., Ivanov, S., Fendrych, M., Faccio, A., Zarsky, V., Bisseling, T., et al. (2012). Multiple exocytotic markers accumulate at the sites of perifungal membrane biogenesis in arbuscular mycorrhizas. Plant Cell Physiol. 53, 244-255.

Gherbi, H., Markmann, K., Svistoonoff, S., Estevan, J., Autran, D., Giczey, G., et al. (2008). SymRK defines a common genetic basis for plant root endosymbioses with arbuscular mycorrhiza fungi, rhizobia, and Frankia bacteria. Proc. Natl. Acad. Sci. U.S.A. 105, 4928-4932.

Gianinazzi-Pearson, V., Arnould, C., Oufattole, M., Arango, M., and Gianinazzi, S. (2000). Differential activation of $\mathrm{H}+$-ATPase genes by an arbuscular mycorrhizal fungus in root cells of transgenic tobacco. Planta 211, 609-613.

Gimenez-Ibanez, S., Hann, D. R., Ntoukakls, V., Petutschnig, E., Lipka, V., and Rathjen, J. P. (2009). AvrPtoB targets the LysM receptor kinase CERK1 to promote bacterial virulence on plants. Curr. Biol. 19, 423-429.

Gomez, S. K., Javot, H., Deewatthanawong, P., Torres-Jerez, I., Tang, Y. H., Blancaflor, E. B., et al. (2009). Medicago truncatula and Glomus intraradices gene expression in cortical cells harboring arbuscules in the arbuscular mycorrhizal symbiosis. BMC Plant Biol. 9. doi: 10.1186/1471-2229-9-10

Gough, C., and Cullimore, J. (2011). Lipo-chitooligosaccharide signaling in endosymbiotic plant-microbe interactions. Mol. Plant Microbe Interact. 24, 867-878.

Govindarajulu, M., Pfeffer, P. E., Jin, H. R., Abubaker, J., Douds, D. D., Allen, J. W., et al. (2005). Nitrogen transfer in the arbuscular mycorrhizal symbiosis. Nature 435, 819-823.

Groth, M., Takeda, N., Perry, J., Uchida, H., Draexl, S., Brachmann, A., et al. (2010). NENA, a Lotus japonicus homolog of Sec13, is required for rhizodermal infection by arbuscular mycorrhiza fungi and rhizobia but dispensable for cortical endosymbiotic development. Plant Cell 22, 2509-2526.

Guether, M., Balestrini, R., Hannah, M., He, J., Udvardi, M., and Bonfante, P. (2009a). Genome-wide reprogramming of regulatory networks, cell wall and membrane biogenesis during arbuscularmycorrhizal symbiosis in Lotus japonicus. New Phytologist 182, 200-212.

Guether, M., Neuhauser, B., Balestrini, R., Dynowski, M., Ludewig, U., and Bonfante, P. (2009b). A mycorrhizal-specific ammonium transporter from Lotus japonicus acquires nitrogen released by arbuscular mycorrhizal fungi. Plant Physiol. 150, 73-83.

Güimil, S., Chang, H. S., Zhu, T., Sesma, A., Osbourn, A., Roux, C., et al. (2005). Comparative transcriptomics of rice reveals an ancient pattern of response to microbial colonization. Proc. Natl. Acad. Sci. U.S.A. 102, 8066-8070.

Gust, A. A., Willmann, R., Desaki, Y., Grabherr, H. M., and Nürnberger, T. (2012). Plant LysM proteins: modules mediating symbiosis and immunity. Trends Plant Sci. 17, 495-502.

Gutjahr, C., Banba, M., Croset, V., An, K., Miyao, A., An, G., et al. (2008). Arbuscular mycorrhizaspecific signaling in rice transcends the common symbiosis signaling pathway. Plant Cell 20, 2989-3005.

Gutjahr, C., Radovanovic, D., Geoffroy, J., Zhang, Q., Siegler, H., Chiapello, M., et al. (2012). The half-size ABC transporters STR1 and STR2 are indispensable for mycorrhizal arbuscule formation in rice. Plant $J$. 69, 906-920.

Guttenberger, M. (2000). Arbuscules of vesicular-arbuscular mycorrhizal fungi inhabit an acidic compartment within plant roots. Planta 211, 299-304.

Hakoyama, T., Niimi, K., Yamamoto, T., Isobe, S., Sato, S., Nakamura, Y., et al. (2012). The integral membrane protein SEN1 is required for symbiotic nitrogen fixation in Lotus japonicus nodules. Plant Cell Physiol. 53, 225-236.

Hammer, E. C., Pallon, J., Wallander, H., and Olsson, P. A. (2011). Tit for tat? A mycorrhizal fungus accumulates phosphorus under low plant carbon availability. FEMS Microbiol. Ecol. 76, 236-244.

Haney, C. H., and Long, S. R. (2010). Plant flotillins are required for infection by nitrogen-fixing bacteria. Proc. Natl. Acad. Sci. U.S.A. 107, 478-483.

Haney, C. H., Riely, B. K., Tricoli, D. M., Cook, D. R., Ehrhardt, D. W. and Long, S. R. (2011). Symbiotic rhizobia bacteria trigger a change in localization and dynamics of the Medicago truncatula receptor kinase LYK3. Plant Cell 23, 2774-2787.

Harrison, M. J. (1996). A sugar transporter from Medicago truncatula: altered expression pattern in roots during vesicular-arbuscular (VA) mycorrhizal associations. Plant J. 9, 491-503.

Harrison, M. J., Dewbre, G. R., and Liu, J. Y. (2002). A phosphate transporter from Medicago truncatula involved in the acquisiton of phosphate released by arbuscular mycorrhizal fungi. Plant Cell 14, 2413-2429.

Harrison, M. J., and Van Buuren, M. L. (1995). A phosphate transporter from the mycorrhizal fungus Glomus versiforme. Nature 378, 626-629.

Hassan, S., and Mathesius, U. (2012). The role of flavonoids in rootrhizosphere signalling: opportunities and challenges for improving plant-microbe interactions. J. Exp. Bot. 63, 3429-3444.

Hause, B., and Fester, T. (2005) Molecular and cell biology of arbuscular mycorrhizal symbiosis. Planta 221, 184-196.

Heckman, D. S., Geiser, D. M., Eidell, B. R., Stauffer, R. L., Kardos, N. L., and Hedges, S. B. (2001). Molecular evidence for the early colonization of land by fungi and plants. Science 293, 1129-1133.

Helber, N., Wippel, K., Sauer, N., Schaarschmidt, S., Hause, B., and Requena, N. (2011). A versatile monosaccharide transporter that operates in the arbuscular mycorrhizal fungus Glomus sp is crucial for the symbiotic relationship with plants. Plant Cell 23, 3812-3823.

Hijikata, N., Murase, M., Tani, C., Ohtomo, R., Osaki, M., and Ezawa, T. (2010). Polyphosphate has a central role in the rapid and massive 
accumulation of phosphorus in extraradical mycelium of an arbuscular mycorrhizal fungus. $\mathrm{New}$ Phytol. 186, 285-289.

Hill, A. E., Shachar-Hill, B., and Shachar-Hill, Y. (2004). What are aquaporins for? J. Membr. Biol. 197, $1-32$.

Hocher, V., Alloisio, N., Auguy, F., Fournier, P., Doumas, P., Pujic, P., et al. (2011). Transcriptomics of actinorhizal symbioses reveals homologs of the whole common symbiotic signaling cascade. Plant Physiol. 156, 700-711.

Hohnjec, N., Vieweg, M. E., Puhler, A., Becker, A., and Kuster, H. (2005). Overlaps in the transcriptional profiles of Medicago truncatula roots inoculated with two different Glomus fungi provide insights into the genetic program activated during arbuscular mycorrhiza. Plant Physiol. 137, 1283-1301.

Horvath, B., Yeun, L. H., Domonkos, A., Halasz, G., Gobbato, E., Ayaydin, F., et al. (2011). Medicago truncatula IPD3 Is a member of the common symbiotic signaling pathway required for rhizobial and mycorrhizal symbioses. Mol. Plant Microbe Interact. 24, 1345-1358.

Hwang, J. H., Ellingson, S. R., and Roberts, D. M. (2010). Ammonia permeability of the soybean nodulin 26 channel. FEBS Lett. 584, 4339-4343.

Ivanov, S., Fedorova, E. E., Limpens, E., De Mita, S., Genre, A., Bonfante, P., et al. (2012). Rhizobium-legume symbiosis shares an exocytotic pathway required for arbuscule formation. Proc. Natl. Acad. Sci. U.S.A. 109, 8316-8321.

Jahn, R., and Scheller, R. H. (2006). SNAREs - engines for membrane fusion. Nat. Rev. Mol. Cell Biol. 7, 631-643.

Jarsch, I. K., and Ott, T. (2011). Perspectives on remorin proteins, membrane rafts, and their role during plant-microbe interactions. Mol. Plant Microbe Interact. 24, 7-12.

Javot, H., Penmetsa, R. V., Terzaghi, N., Cook, D. R., and Harrison, M. J. (2007). A Medicago truncatula phosphate transporter indispensable for the arbuscular mycorrhizal symbiosis. Proc. Natl. Acad. Sci. U.S.A. 104, 1720-1725.

Jones, K. M., Kobayashi, H., Davies, B. W., Taga, M. E., and Walker, G. C. (2007). How rhizobial symbionts invade plants: the Sinorhizobium-Medicago model. Nat. Rev. Microbiol. 5, 619-633.

Kaiser, B. N., Finnegan, P. M., Tyerman, S. D., Whitehead, L. F., Bergersen,
F. J., Day, D. A., et al. (1998). Characterization of an ammonium transport protein from the peribacteroid membrane of soybean nodules. Science 281 , 1202-1206.

Kaku, H., Nishizawa, Y., Ishii-Minami, N., Akimoto-Tomiyama, C., Dohmae, N., Takio, K., et al. (2006). Plant cells recognize chitin fragments for defense signaling through a plasma membrane receptor. Proc. Natl. Acad. Sci. U.S.A. 103, 11086-11091.

Kalde, M., Nuhse, T. S., Findlay, K., and Peck, S. C. (2007). The syntaxin SYP132 contributes to plant resistance against bacteria and secretion of pathogenesis-related protein 1 . Proc. Natl. Acad. Sci. U.S.A. 104, 11850-11855.

Kambara, K., Ardissone, S., Kobayashi, H., Saad, M. M., Schumpp, O., Broughton, W. J., et al. (2009). Rhizobia utilize pathogen-like effector proteins during symbiosis. Mol. Microbiol. 71, 92-106.

Kanamori, N., Madsen, L. H., Radutoiu, S., Frantescu, M., Quistgaard, E. M. H., Miwa, H., et al. (2006). A nucleoporin is required for induction of $\mathrm{Ca} 2+$ spiking in legume nodule development and essential for rhizobial and fungal symbiosis. Proc. Natl. Acad. Sci. U.S.A. 103, 359-364.

Karandashov, V., and Bucher, M. (2005). Symbiotic phosphate transport in arbuscular mycorrhizas. Trends Plant Sci. 10, 22-29.

Keinath, N. F., Kierszniowska, S., Lorek, J., Bourdais, G., Kessler, S. A., Shimosato-Asano, H., et al. (2010). PAMP (Pathogen-associated Molecular Pattern)-induced changes in plasma membrane compartmentalization reveal novel components of plant immunity. J. Biol. Chem. 285, 39140-39149.

Kevei, Z., Lougnon, G., Mergaert, P., Horvath, G. V., Kereszt, A., Jayaraman, D., et al. (2007). 3-hydroxy-3-methylglutaryl coenzyme A reductasel interacts with NORK and is crucial for nodulation in Medicago truncatula. Plant Cell 19, 3974-3989.

Khan, W., Costa, C., Souleimanov, A., Prithiviraj, B., and Smith, D. L. (2011). Response of Arabidopsis thaliana roots to lipo-chitooligosaccharide from Bradyrhizobium japonicum and other chitin-like compounds. Plant Growth Regul. 63, 243-249.

Kiers, E. T., Duhamel, M., Beesetty, Y., Mensah, J. A., Franken, O., Verbruggen, E., et al. (2011). Reciprocal rewards stabilize cooperation in the mycorrhizal symbiosis. Science 333, 880-882.

Kistner, C., and Parniske, M. (2002). Evolution of signal transduction in intracellular symbiosis. Trends Plant Sci. 7, 511-518.

Kloppholz, S., Kuhn, H., and Requena, N. (2011). A secreted fungal effector of Glomus intraradices promotes symbiotic biotrophy. Curr. Biol. 21, 1204-1209.

Kobae, Y., and Hata, S. (2010). Dynamics of periarbuscular membranes visualized with a fluorescent phosphate transporter in arbuscular mycorrhizal roots of rice. Plant Cell Physiol. 51, 341-353.

Kobae, Y., Tamura, Y., Takai, S., Banba, M., and Hata, S. (2010). Localized expression of arbuscular mycorrhiza-inducible ammonium transporters in soybean. Plant Cell Physiol. 51, 1411-1415.

Kosuta, S., Hazledine, S., Sun, J., Miwa, H., Morris, R. J., Downie, J. A., et al. (2008). Differential and chaotic calcium signatures in the symbiosis signaling pathway of legumes. Proc. Natl. Acad. Sci. U.S.A. 105, 9823-9828.

Krajinski, F., Hause, B., GianinazziPearson, V., and Franken, P. (2002). Mthal, a plasma membrane $\mathrm{H}+$-ATPase gene from Medicago truncatula, shows arbuscule-specific induced expression in mycorrhizal tissue. Plant Biol. 4, 754-761.

Kretzschmar, T., Kohlen, W., Sasse, J., Borghi, L., Schlegel, M., Bachelier, J. B., et al. (2012). A petunia $\mathrm{ABC}$ protein controls strigolactonedependent symbiotic signalling and branching. Nature 483, 341-346.

Kuga, Y., Saito, K., Nayuki, K., Peterson, R. L., and Saito, M. (2008). Ultrastructure of rapidly frozen and freeze-substituted germ tubes of an arbuscular mycorrhizal fungus and localization of polyphosphate. New Phytol. 178, 189-200.

Kuhn, H., Kuster, H., and Requena, N. (2010). Membrane steroid-binding protein 1 induced by a diffusible fungal signal is critical for mycorrhization in Medicago truncatula. New Phytol. 185, 716-733.

Kwon, C., Neu, C., Pajonk, S., Yun, H. S., Lipka, U., Humphry, M., et al. (2008). Co-option of a default secretory pathway for plant immune responses. Nature 451, 835-840.

Lefebvre, B., Timmers, T., Mbengue, M., Moreau, S., Herve, C., Toth, K., et al. (2010). A remorin protein interacts with symbiotic receptors and regulates bacterial infection. Proc. Natl. Acad. Sci. U.S.A. 107, 2343-2348.
Lev, S., Ben Halevy, D., Peretti, D., and Dahan, N. (2008). The VAP protein family: from cellular functions to motor neuron disease. Trends Cell Biol. 18, 282-290.

Lewis, J. D., Lee, A., Ma, W. B., Zhou, H. B., Guttman, D. S., and Desveaux D. (2011). The YopJ superfamily in plant-associated bacteria. Mol. Plant Pathol. 12, 928-937.

Leyman, B., Geelen, D., Quintero, F. J., and Blatt, M. R. (1999). A tobacco syntaxin with a role in hormonal control of guard cell ion channels. Science 283, 537-540.

Li, H. Y., Smith, F. A., Dickson, S., Holloway, R. E., and Smith, S. E. (2008). Plant growth depressions in arbuscular mycorrhizal symbioses: not just caused by carbon drain? New Phytol. 178, 852-862.

Ligrone, R., Duckett, J. G., and Renzaglia, K. S. (2012). Major transitions in the evolution of early land plants: a bryological perspective. Ann. Bot. 109, 851-871.

Limpens, E., Ivanov, S., Van Esse, W., Voets, G., Fedorova, E., and Bisseling, T. (2009). Medicago $\mathrm{N}$-2-fixing symbiosomes acquire the endocytic identity marker Rab7 but delay the acquisition of vacuolar identity. Plant Cell 21, 2811-2828.

Limpens, E., Mirabella, R., Fedorova, E., Franken, C., Franssen, H., Bisseling, T., et al. (2005). Formation of organelle-like N2-fixing symbiosomes in legume root nodules is controlled by DMI2. Proc. Natl. Acad. Sci. U.S.A. 102, 10375-10380.

Liu, T. T., Liu, Z. X., Song, C. J., Hu, Y. F., Han, Z. F., She, J., et al. (2012). Chitin-induced dimerization activates a plant immune receptor. Science 336, 1160-1164.

Lohmann, G. V., Shimoda, Y., Nielsen, M. W., Jorgensen, F. G., Grossmann, C., Sandal, N., et al. (2010). Evolution and regulation of the Lotus japonicus LysM receptor gene family. Mol. Plant Microbe Interact. 23, 510-521.

Lohse, S., Hause, B., Hause, G., and Fester, T. (2006). FtsZ characterization and immunolocalization in the two phases of plastid reorganization in arbuscular mycorrhizal roots of Medicago truncatula. Plant Cell Physiol. 47, 1124-1134.

Lohse, S., Schliemann, W., Ammer, C., Kopka, J., Strack, D., and Fester, T. (2005). Organization and metabolism of plastids and mitochondria in arbuscular mycorrhizal roots of Medicago truncatula. Plant Physiol. 139, 329-340. 
Long, S. R. (1989). Rhizobium-legume nodulation - life together in the underground. Cell 56, 203-214.

Lopez-Pedrosa, A., Gonzalez-Guerrero, M., Valderas, A., Azcon-Aguilar, C., and Ferrol, N. (2006). GintAMT1 encodes a functional high-affinity ammonium transporter that is expressed in the extraradical mycelium of Glomus intraradices. Fungal Genet. Biol. 43, 102-110.

Lovering, A. L., Safadi, S. S., and Strynadka, N. C. J. (2012). Structural perspective of peptidoglycan biosynthesis and assembly. Annu. Rev. Biochem. 81, 451-478.

Madsen, E. B., Antolı'N-Llovera, M., Grossmann, G., Ye, J., Vieweg, S., Broghammer, A., et al. (2011). Autophosphorylation is essential for the in vivo function of the Lotus japonicus Nod factor receptor 1 and receptor-mediated signalling in cooperation with Nod factor receptor 5. Plant J. 65, 404-417.

Madsen, E. B., Madsen, L. H., Radutoiu, S., Olbryt, M., Rakwalska, M., Szczyglowski, K., et al. (2003). A receptor kinase gene of the LysM type is involved in legume perception of rhizobial signals. Nature 425, 637-640.

Maeda, D., Ashida, K., Iguchi, K., Chechetka, S. A., Hijikata, A., Okusako, Y., et al. (2006). Knockdown of an arbuscular mycorrhiza-inducible phosphate transporter gene of Lotus japonicus suppresses mutualistic symbiosis. Plant Cell Physiol. 47, 807-817.

Maillet, F., Poinsot, V., André, O., Puech-Pagès, V., Haouy, A., Gueunier, M., et al. (2011). Fungal lipochitooligosaccharide symbiotic signals in arbuscular mycorrhiza. Nature 469, 58-64.

Maldonado-Mendoza, I. E., Dewbre, G. R., and Harrison, M. J. (2001). A phosphate transporter gene from the extra-radical mycelium of an arbuscular mycorrhizal fungus Glomus intraradices is regulated in response to phosphate in the environment. Mol. Plant Microbe Interact. 14, 1140-1148.

Markmann, K., Giczey, G., and Parniske, M. (2008). Functional adaptation of a plant receptorkinase paved the way for the evolution of intracellular root symbioses with bacteria. PLoS Biol. 6:e68. doi: 10.1371/journal.pbio.0060068

Martinez-Romero, E. (2009). Coevolution in rhizobium-legume symbiosis? DNA Cell Biol. 28, 361-370.
Marulanda, A., Azcon, R., and RuizLozano, J. M. (2003). Contribution of six arbuscular mycorrhizal fungal isolates to water uptake by Lactuca sativa plants under drought stress. Physiologia Plantarum 119, 526-533.

Marx, C., Dexheimer, J., GianinazziPearson, V., and Gianinazzi, S. (1982). Enzymatic studies on the metabolism of vesiculararbuscular mycorrhizas. 4 Ultracytoenzymological evidence (ATPase) for active transfer processes in the host-arbuscule interface. New Phytol. 90, 37-43.

Maurel, C., Santoni, V., Luu, D. T., Wudick, M. M., and Verdoucq, L. (2009). The cellular dynamics of plant aquaporin expression and functions. Curr. Opin. Plant Biol. 12, 690-698.

Mbengue, M., Camut, S., De CarvalhoNiebel, F., Deslandes, L., Froidure, S., Klaus-Heisen, D., et al. (2010). The Medicago truncatula E3 ubiquitin ligase PUB1 interacts with the LYK3 symbiotic receptor and negatively regulates infection and nodulation. Plant Cell 22, 3474-3488.

Mellor, R. B. (1989). Bacteroids in the Rhizobium-legume symbiosis inhabit a plant internal lytic compartment - implications for other microbial endosymbioses. J. Exp. Bot. 40, 831-839.

Merckx, V. S. F. T., Janssens, J. B., Hynson, N. A., Specht, C. D., Bruns, T. D., and Smets, E. F. (2012). Mycoheterotrophic interactions are not limited to a narrow phylogenetic range of arbuscular mycorrhizal fungi. Mol. Ecol. 21, 1524-1532.

Messinese, E., Mun, J. H., Yeun, L. H., Jayaraman, D., Rouge, P. Barre, A., et al. (2007). A novel nuclear protein interacts with the symbiotic DMI3 calcium- and calmodulin-dependent protein kinase of Medicago truncatula. Mol. Plant Microbe Interact. 20, 912-921.

Miya, A., Albert, P., Shinya, T., Desaki, Y., Ichimura, K., Shirasu, K., et al. (2007). CERK1, a LysM receptor kinase, is essential for chitin elicitor signaling in Arabidopsis. Proc. Natl. Acad. Sci. U.S.A. 104, 19613-19618.

Mosavi, L. K., Cammett, T. J., Desrosiers, D. C., and Peng, Z. Y. (2004). The ankyrin repeat as molecular architecture for protein recognition. Protein Sci. 13, 1435-1448.

Murray, J. D., Duvvuru Muni, R., Torres-Jerez, I., Tang, Y., Allen, S., Andriankaja, M., et al. (2011). Vapyrin, a gene essential for intracellular progression of arbuscular mycorrhizal symbiosis, is also essential for infection by rhizobia in the nodule symbiosis of Medicago truncatula. Plant J. 65, 244-252.

Nagy, R., Drissner, D., Amrhein N., Jakobsen, I., and Bucher, M. (2009). Mycorrhizal phosphate uptake pathway in tomato is phosphorus-repressible and transcriptionally regulated. New Phytol. 181, 950-959.

Naisbitt, T., James, E. K., and Sprent, J. I. (1992). The evolutionary significance of the legume genus Chamaecrista, as determined by nodule structure. New Phytol. 122, 487-492.

Nakagawa, T., Kaku, H., Shimoda, Y., Sugiyama, A., Shimamura, M. Takanashi, K., et al. (2011). From defense to symbiosis: limited alterations in the kinase domain of LysM receptor-like kinases are crucial for evolution of legume-Rhizobium symbiosis. Plant J. 65, 169-180.

Oldroyd, G. E. D., and Downie, J. A. (2006). Nuclear calcium changes at the core of symbiosis signalling. Curr. Opin. Plant Biol. 9, 351-357.

Oldroyd, G. E. D., and Downie, J. A (2008). Coordinating nodule morphogenesis with rhizobial infection in legumes. Annu. Rev. Plant Biol. 59, 519-546.

Oldroyd, G. E. D., Murray, J. D. Poole, P. S., and Downie, J. A. (2011). The rules of engagement in the legume-rhizobial symbiosis. Ann. Rev. Genet. 45, 119-144.

Olsson, P. A., Hammer, E. C., Pallon, J., Van Aarle, I. M., and Wallander H. (2011). Elemental composition in vesicles of an arbuscular mycorrhizal fungus, as revealed by PIXE analysis. Fungal Biol. 115, 643-648

Olsson, P. A., Rahm, J., and Aliasgharzad, N. (2010). Carbon dynamics in mycorrhizal symbioses is linked to carbon costs and phosphorus benefits. FEMS Microbiol. Ecol. 72, 123-131.

Op Den Camp, R., Streng, A., De Mita, S., Cao, Q., Polone, E., Liu, W. et al. (2011). LysM-type mycorrhizal receptor recruited for Rhizobium symbiosis in nonlegume Parasponia. Science 331, 909-912.

Ovchinnikova, E., Journet, E. P., Chabaud, M., Cosson, V., Ratet, P. Duc, G., et al. (2011). IPD3 controls the formation of nitrogen-fixing symbiosomes in pea and Medicago Spp. Mol. Plant Microbe Interact. 24 1333-1344.

Parniske, M. (2008). Arbuscular mycorrhiza: the mother of plant root endosymbioses. Nat. Rev. Microbiol. 6, 763-775.
Paszkowski, U., Kroken, S., Roux, C., and Briggs, S. P. (2002). Rice phosphate transporters include an evolutionarily divergent gene specifically activated in arbuscular mycorrhizal symbiosis. Proc. Natl. Acad. Sci. U.S.A. 99, 13324-13329.

Pawlowski, K., and Demchenko, K. N. (2012). The diversity of actinorhizal symbiosis. Protoplasma. doi: 10.1007/s00709-012-0388-4. [Epub ahead of print].

Peiter, E., Sun, J., Heckmann, A. B., Venkateshwaran, M., Riely, B. K., Otegui, M. S., et al. (2007). The Medicago truncatula DMI1 protein modulates cytosolic calcium signaling. Plant Physiol. 145, 192-203.

Perez-Tienda, J., Testillano, P. S., Balestrini, R., Fiorilli, V., AzconAguilar, C., and Ferrol, N. (2011). GintAMT2, a new member of the ammonium transporter family in the arbuscular mycorrhizal fungus Glomus intraradices. Fungal Genet. Biol. 48, 1044-1055.

Petutschnig, E. K., Jones, A. M. E., Serazetdinova, L., Lipka, U., and Lipka, V. (2010). The lysin motif receptor-like kinase (LysM-RLK) CERK1 Is a major chitin-binding protein in Arabidopsis thaliana and subject to chitin-induced phosphorylation. J. Biol. Chem. 285, 28902-28911.

Pfeffer, P. E., Douds, D. D., Becard, G., and Shachar-Hill, Y. (1999). Carbon uptake and the metabolism and transport of lipids in an arbuscular mycorrhiza. Plant Physiol. 120, 587-598.

Pini, F., Frascella, A., Santopolo, L., Bazzicalupo, M., Biondi, E. G., Scotti, C., et al. (2012). Exploring the plant-associated bacterial communities in Medicago sativa L. BMC Microbiology 12, 78.

Pratelli, J., Sutter, J. U., and Blatt, M. R. (2004). A new catch in the SNARE. Trends Plant Sci. 9, 187-195.

Prell, J., and Poole, P. (2006). Metabolic changes of rhizobia in legume nodules. Trends Microbiol. 14, 161-168.

Pumplin, N., and Harrison, M. J. (2009). Live-cell imaging reveals periarbuscular membrane domains and organelle location in Medicago truncatula roots during arbuscular mycorrhizal symbiosis. Plant Physiol. 151, 809-819.

Pumplin, N., Mondo, S. J., Topp, S., Starker, C. G., Gantt, J. S., and Harrison, M. J. (2010). Medicago truncatula Vapyrin is a novel protein required for arbuscular mycorrhizal symbiosis. Plant J. 61, 482-494. 
Pumplin, N., Zhang, X., Noar, R. D., and Harrison, M. J. (2012). Polar localization of a symbiosis-specific phosphate transporter is mediated by a transient reorientation of secretion. Proc. Natl. Acad. Sci. U.S.A. 109, E665-E672.

Radutoiu, S., Madsen, L. H., Madsen, E. B., Felle, H. H., Umehara, Y., Gronlund, M., et al. (2003). Plant recognition of symbiotic bacteria requires two LysM receptor-like kinases. Nature 425, 585-592.

Radutoiu, S., Madsen, L. H., Madsen, E. B., Jurkiewicz, A., Fukai, E., Quistgaard, E. M. H., et al. (2007). LysM domains mediate lipochitinoligosaccharide recognition and $\mathrm{Nfr}$ genes extend the symbiotic host range. EMBO J. 26, 3923-3935.

Ramos, A. C., Martins, M. A., Okorokova-Facanha, A. L., Olivares, F. L., Okorokov, L. A., Sepulveda, N., et al. (2009). Arbuscular mycorrhizal fungi induce differential activation of the plasma membrane and vacuolar $\mathrm{H}+$ pumps in maize roots. Mycorrhiza 19, 69-80.

Rausch, C., Daram, P., Brunner, S., Jansa, J., Laloi, M., Leggewie, G., et al. (2001). A phosphate transporter expressed in arbusculecontaining cells in potato. Nature 414, 462-466.

Redecker, D., Kodner, R., and Graham, L. E. (2000). Glomalean fungi from the Ordovician. Science 289, 1920-1921.

Requena, N., Breuninger, M., Franken, P., and Ocón, A. (2003). Symbiotic status, phosphate, and sucrose regulate the expression of two plasma membrane $\mathrm{H}+$-ATPase genes from the mycorrhizal fungus Glomus mosseae. Plant Physiol. 132, 1540-1549.

Riely, B. K., Lougnon, G., Ané, J. M., and Cook, D. R. (2007). The symbiotic ion channel homolog DMI1 is localized in the nuclear membrane of Medicago truncatula roots. Plant J. 49, 208-216.

Rivers, R. L., Dean, R. M., Chandy, G., Hall, J. E., Roberts, D. M., and Zeidel, M. L. (1997). Functional analysis of nodulin 26, an aquaporin in soybean root nodule symbiosomes. J. Biol. Chem. 272, 16256-16261.

Robertson, J. G., and Lyttleton, P. (1982). Coated and smooth vesicles in the biogenesis of cell walls, plasma membranes, infection threads and peribacteroid membranes in root hairs and nodules of white clover. J. Cell. Sci. 58, 63-78.

Rogato, A., D’Apuzzo, E., Barbulova, A., Omrane, S., Stedel, C.,
Simon-Rosin, U., et al. (2008). Tissue-specific down-regulation of LjAMT1;1 compromises nodule function and enhances nodulation in Lotus japonicus. Plant Mol. Biol. 68, 585-595.

Saalbach, G., Erik, P., and Wienkoop, S. (2002). Characterisation by proteomics of peribacteroid space and peribacteroid membrane preparations from pea (Pisum sativum) symbiosomes. Proteomics 2, 325-337.

Saito, C., Ueda, T., Abe, H., Wada, Y., Kuroiwa, T., Hisada, A., et al. (2002). A complex and mobile structure forms a distinct subregion within the continuous vacuolar membrane in young cotyledons of Arabidopsis. Plant J. 29, 245-255.

Saito, K., Yoshikawa, M., Yano, K. Miwa, H., Uchida, H., Asamizu, E., et al. (2007). NUCLEOPORIN85 is required for calcium spiking, fungal and bacterial symbioses, and seed production in Lotus japonicus. Plant Cell 19, 610-624.

Sekhara Reddy, D. M. R., Schorderet, M., Feller, U., and Reinhardt, D. (2007). A petunia mutant affected in intracellular accommodation and morphogenesis of arbuscular mycorrhizal fungi. Plant J. 51, 739-750.

Sharda, J. N., and Koide, R. T. (2008). Can hypodermal passage cell distribution limit root penetration by mycorrhizal fungi? New Phytol. 180, 696-701.

Shimizu, T., Nakano, T., Takamizawa, D., Desaki, Y., Ishii-Minami, N. Nishizawa, Y., et al. (2010). Two LysM receptor molecules, CEBiP and OsCERK1, cooperatively regulate chitin elicitor signaling in rice. Plant J. 64, 204-214.

Shinya, T., Motoyama, N., Ikeda, A., Wada, M., Kamiya, K., Hayafune, M., et al. (2012). Functional characterization of $\mathrm{CEBiP}$ and CERK1 homologs in Arabidopsis and rice reveals the presence of different chitin receptor systems in plants. Plant Cell Physiol. doi: 10.1093/pcp/pcs113. [Epub ahead of print].

Simon-Plas, F., Perraki, A., Bayer, E., Gerbeau-Pissot, P., and Mongrand, S. (2011). An update on plant membrane rafts. Curr. Opin. Plant Biol. 14, 642-649.

Simons, K., and Ikonen, E. (1997). Functional rafts in cell membranes. Nature 387, 569-572.

Singer, S. J., and Nicolson, G. L. (1972). Fluid mosaic model of structure of cell membranes. Science 175, $720-731$.

Singh, S., and Parniske, M. (2012). Activation of calcium- and calmodulin-dependent protein kinase (CCaMK), the central regulator of plant root endosymbiosis. Curr. Opin. Plant Biol. 15, 444-453.

Smit, P., Limpens, E., Geurts, R. Fedorova, E., Dolgikh, E., Gough, C., et al. (2007). Medicago LYK3, an entry receptor in rhizobial nodulation factor signaling. Plant Physiol. $145,183-191$

Smith, S., and Read, D. (2008) Mycorrhizal Symbiosis. New York, NY: Academic Press.

Smith, S. E., and Smith, F. A. (2011). Roles of arbuscular mycorrhizas in plant nutrition and growth: new paradigms from cellular to ecosystem scales. Annu. Rev. Plant Biol. 62, 227-250.

Soltis, D. E., Soltis, P. S., Morgan, D. R., Swensen, S. M., Mullin, B. C., Dowd, J. M., et al. (1995). Chloroplast gene sequence data suggest a single origin of predisposition for symbiotic nitrogen fixation in angiosperms. Proc. Natl. Acad. Sci. U.S.A. 92, 2647-2651.

Soto, M. J., Nogales, J., Perez-Mendoza, D., Gallegos, M. T., Olivares, J., and Sanjuan, J. (2011). Pathogenic and mutualistic plant-bacteria interactions: ever increasing similarities. Central Eur. J. Biol. 6, 911-917.

Spaink, H. P. (1995). The molecular basis of infection and nodulation by rhizobia - the ins and outs of sympathogenesis. Annu. Rev. Phytopathol. 33, 345-368.

Starker, C. G., Parra-Colmenares, A L., Smith, L., Mitra, R. M., and Long, S. R. (2006). Nitrogen fixation mutants of Medicago truncatula fail to support plant and bacterial symbiotic gene expression. Plant Physiol. 140, 671-680.

Strack, D., and Fester, T. (2006). Isoprenoid metabolism and plastid reorganization in arbuscular mycorrhizal roots. New Phytol. 172, 22-34.

Stracke, S., Kistner, C., Yoshida, S. Mulder, L., Sato, S., Kaneko, T., et al. (2002). A plant receptor-like kinase required for both bacterial and fungal symbiosis. Nature 417, 959-962.

Tanner, W., Malinsky, J., and Opekarova, M. (2011). In plant and animal cells, detergent-resistant membranes do not define functional membrane rafts. Plant Cell 23, 1191-1193.

Tena, G., Boudsocq, M., and Sheen, J. (2011). Protein kinase signaling networks in plant innate immunity. Curr. Opin. Plant Biol. 14, 519-529.

Tian, C. J., Kasiborski, B., Koul, R. Lammers, P. J., Bucking, H., and
Shachar-Hill, Y. (2010). Regulation of the nitrogen transfer pathway in the arbuscular mycorrhizal symbiosis: gene characterization and the coordination of expression with nitrogen flux. Plant Physiol. 153, 1175-1187.

Timmers, A. C. J., Auriac, M. C., De Billy, F., and Truchet, G. (1998). Nod factor internalization and microtubular cytoskeleton changes occur concomitantly during nodule differentiation in alfalfa. Development 125, 339-349.

Toth, K., Stratil, T. F., Madsen, E. B., Ye, J. Y., Popp, C., Antolin-Llovera, M., et al. (2012). Functional domain analysis of the remorin protein LjSYMREM1 in Lotus japonicus. PLoS ONE 7:e30817. doi: 10.1371/journal.pone.0030817

Tyerman, S. D., Whitehead, L. F., and Day, D. A. (1995). A channel-like transporter for $\mathrm{NH} 4+$ on the symbiotic interface of N2-fixing plants. Nature 378, 629-632.

Uehlein, N., Otto, B., Hanson, D. T. Fischer, M., McDowell, N., and Kaldenhoff, R. (2008). Function of Nicotiana tabacum aquaporins as chloroplast gas pores challenges the concept of membrane CO2 permeability. Plant Cell 20, 648-657.

Uetake, Y., Kojima, T., Ezawa, T., and Saito, M. (2002). Extensive tubular vacuole system in an arbuscular mycorrhizal fungus, Gigaspora margarita. New Phytol. 154, 761-768.

Van Brussel, A. A. N., Bakhuizen, R., Vanspronsen, P. C., Spaink, H. P., Tak, T., Lugtenberg, B. J. J., et al. (1992). Induction of preinfection thread structures in the leguminous host plant by mitogenic lipooligosaccharides of Rhizobium. Science 257, 70-72.

Van De Velde, W., Zehirov, G. Szatmari, A., Debreczeny, M., Ishihara, H., Kevei, Z., et al. (2010). Plant peptides govern terminal differentiation of bacteria in symbiosis. Science 327, 1122-1126.

Verma, D. P. S., Kazazian, V., Zogbi, V. and Bal, A. K. (1978). Isolation and characterization of membrane envelope enclosing bacteroids in soybean root-nodules. J. Cell Biol. 78, 919-936.

Walter, M. H., Floss, D. S., and Strack, D. (2010). Apocarotenoids: hormones, mycorrhizal metabolites and aroma volatiles. Planta 232, $1-17$.

Wan, J., Tanaka, K., Zhang, X.-C., Son, G. H., Brechenmacher, L., Nguyen, T. H. N., et al. (2012). LYK4, a 
LysM receptor-like kinase, is important for chitin signaling and plant innate immunity in Arabidopsis. Plant Physiol. 160, 396-406.

Wan, J. R., Zhang, X. C., Neece, D., Ramonell, K. M., Clough, S., Kim, S. Y., et al. (2008). A LysM receptorlike kinase plays a critical role in chitin signaling and fungal resistance in Arabidopsis. Plant Cell 20, 471-481.

Wang, B., and Qiu, Y. L. (2006). Phylogenetic distribution and evolution of mycorrhizas in land plants. Mycorrhiza 16, 299-363.

Wang, B., Yeun, L. H., Xue, J. Y., Liu, Y., Ane, J. M., and Qiu, Y. L. (2010a). Presence of three mycorrhizal genes in the common ancestor of land plants suggests a key role of mycorrhizas in the colonization of land by plants. New Phytol. 186, 514-525.

Wang, D., Griffitts, J., Starker, C., Fedorova, E., Limpens, E., Ivanov, S., et al. (2010b). A nodule-specific protein secretory pathway required for nitrogen-fixing symbiosis. Science 327, 1126-1129.

Wang, D., and Dong, X. N. (2011). A highway for war and peace: the secretory pathway in plantmicrobe interactions. Mol. Plant 4, 581-587.

Wang, D., Yang, S. M., Tang, F. and Zhu, H. Y. (2012). Symbiosis specificity in the legume - rhizobial mutualism. Cell. Microbiol. 14, 334-342.

Wegmüller, S., Svistoonoff, S., Reinhardt, D., Stuurman, J., Amrhein, N., and Bucher, M. (2008). A transgenic dTph1 insertional mutagenesis system for forward genetics in mycorrhizal phosphate transport of Petunia. Plant J. 54, 1115-1127.

Willmann, R., Lajunen, H. M., Erbs, G., Newman, M.-A., Kolb, D., Tsuda, K., et al. (2011). Arabidopsis lysin-motif proteins LYM1 LYM3 CERK1 mediate bacterial peptidoglycan sensing and immunity to bacterial infection. Proc. Natl. Acad. Sci. U.S.A. 108, 19824-19829.

Yano, K., Yoshida, S., Muller, J., Singh, S., Banba, M., Vickers, K., et al. (2008). CYCLOPS, a mediator of symbiotic intracellular accommodation. Proc. Natl. Acad. Sci. U.S.A. 105, 20540-20545.
Yun, H. S., and Kwon, C. (2012). Trafficking at the host cell surface during plant immune responses. J. Plant Biol. 55, 185-190.

Yurgel, S. N., and Kahn, M. L. (2005). Sinorhizobium meliloti dctA mutants with partial ability to transport dicarboxylic acids. J. Bacteriol. 187, 1161-1172.

Zamioudis, C., and Pieterse, C. M. J. (2012). Modulation of host immunity by beneficial microbes. Mol. Plant Microbe Interact. 25, 139-150.

Zeng, L., Velasquez, A. C., Munkvold, K. R., Zhang, J., and Martin, G. B. (2012). A tomato LysM receptorlike kinase promotes immunity and its kinase activity is inhibited by AvrPtoB. Plant J. 69, 92-103.

Zeuthen, T. (2010). Water-transporting proteins. J. Membr. Biol. 234, 57-73.

Zhang, Q., Blaylock, L. A., and Harrison, M. J. (2010). Two Medicago truncatula half-ABC transporters are essential for arbuscule development in arbuscular mycorrhizal symbiosis. Plant Cell 22, 1483-1497.

Zhang, X. C., Cannon, S. B., and Stacey, G. (2009). Evolutionary genomics of LysM genes in land plants. BMC Evol. Biol. 9, 183.

Conflict of Interest Statement: The authors declare that the research was conducted in the absence of any commercial or financial relationships that could be construed as a potential conflict of interest.

Received: 03 July 2012; accepted: 14 September 2012; published online: 05 October 2012.

Citation: Bapaume L and Reinhardt D (2012) How membranes shape plant symbioses: signaling and transport in nodulation and arbuscular mycorrhiza. Front. Plant Sci. 3:223. doi: 10.3389/fpls. 2012.00223

This article was submitted to Frontiers in Plant Traffic and Transport, a specialty of Frontiers in Plant Science.

Copyright (C) 2012 Bapaume and Reinhardt. This is an open-access article distributed under the terms of the Creative Commons Attribution License, which permits use, distribution and reproduction in other forums, provided the original authors and source are credited and subject to any copyright notices concerning any third-party graphics etc. 


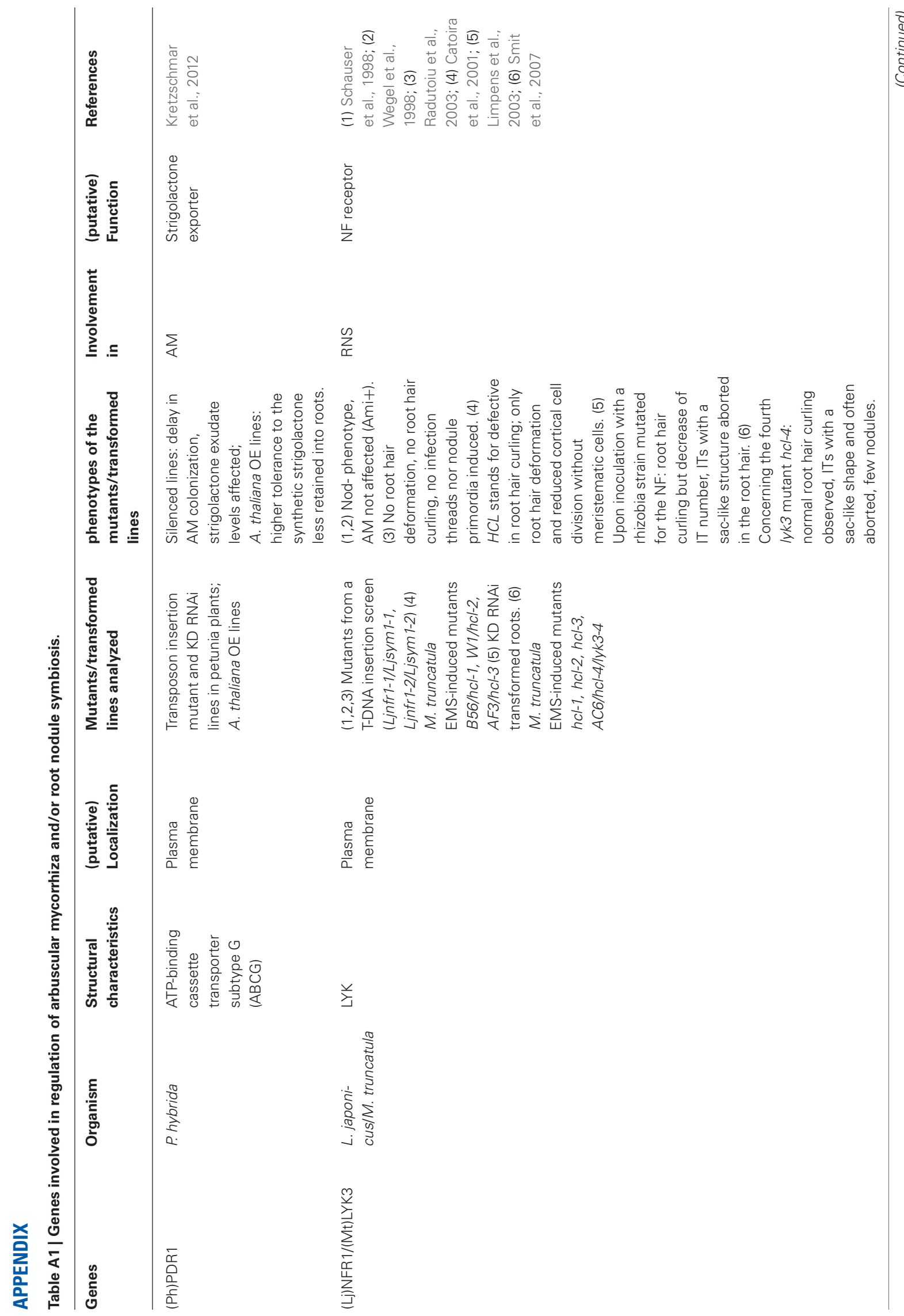




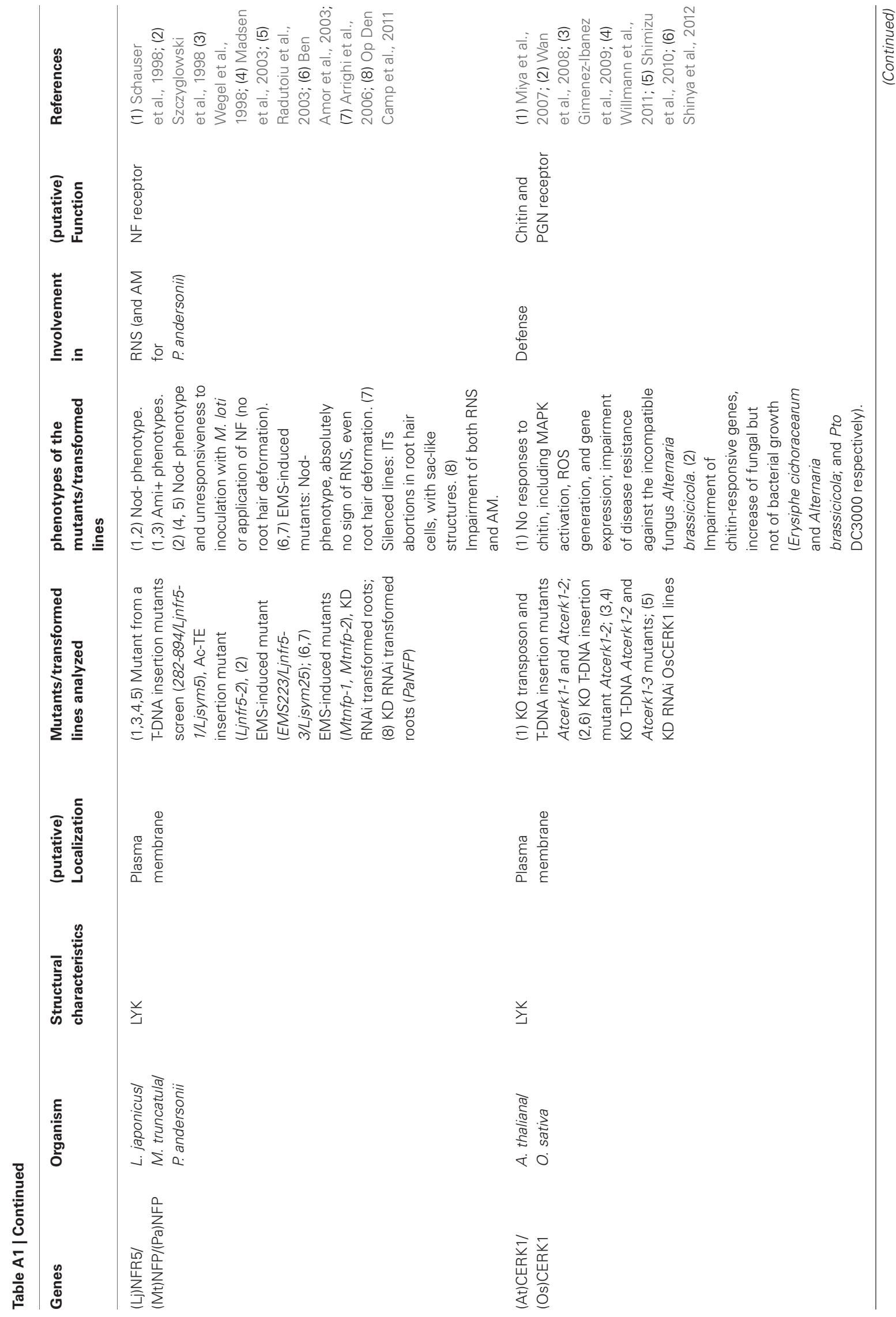




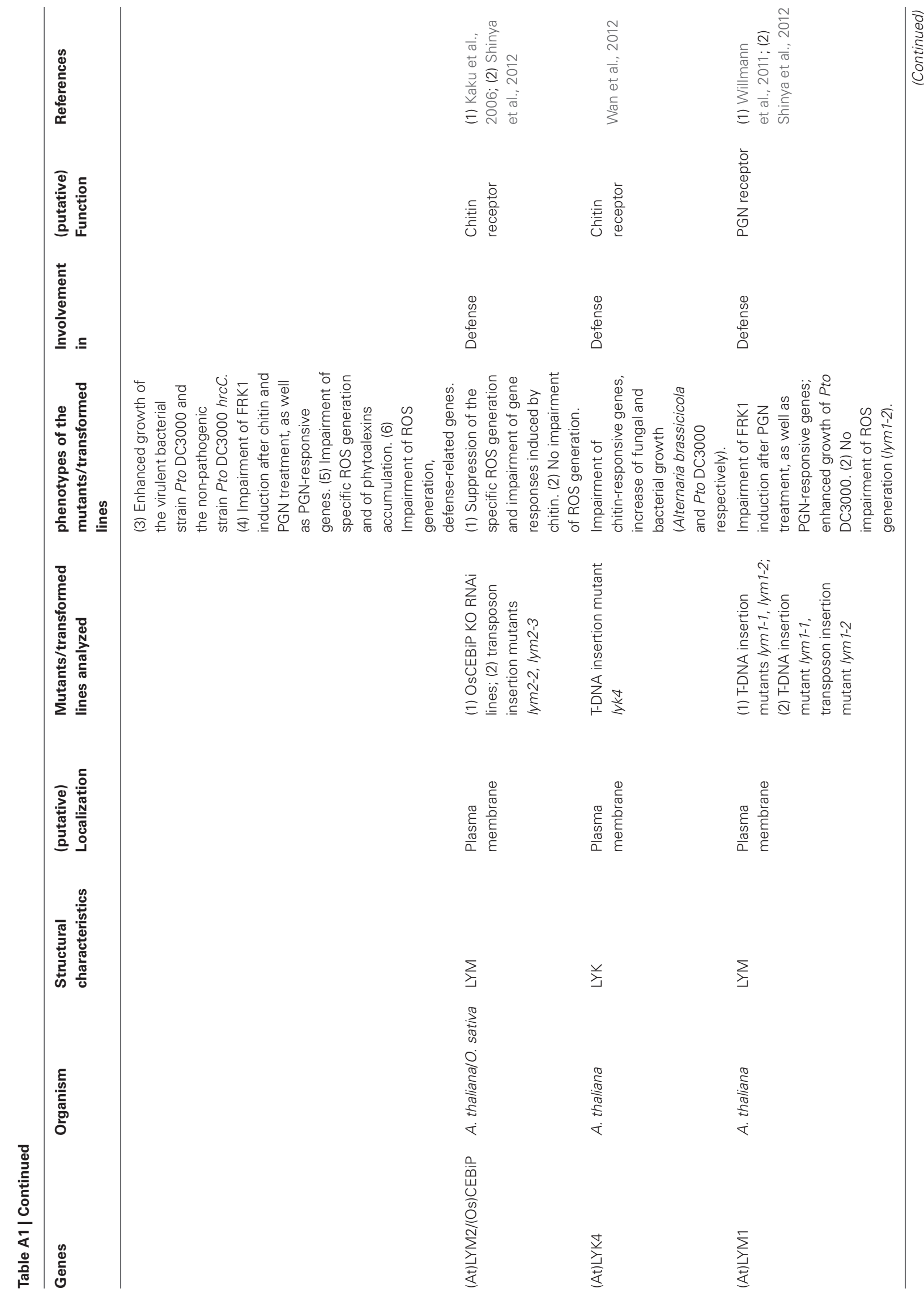




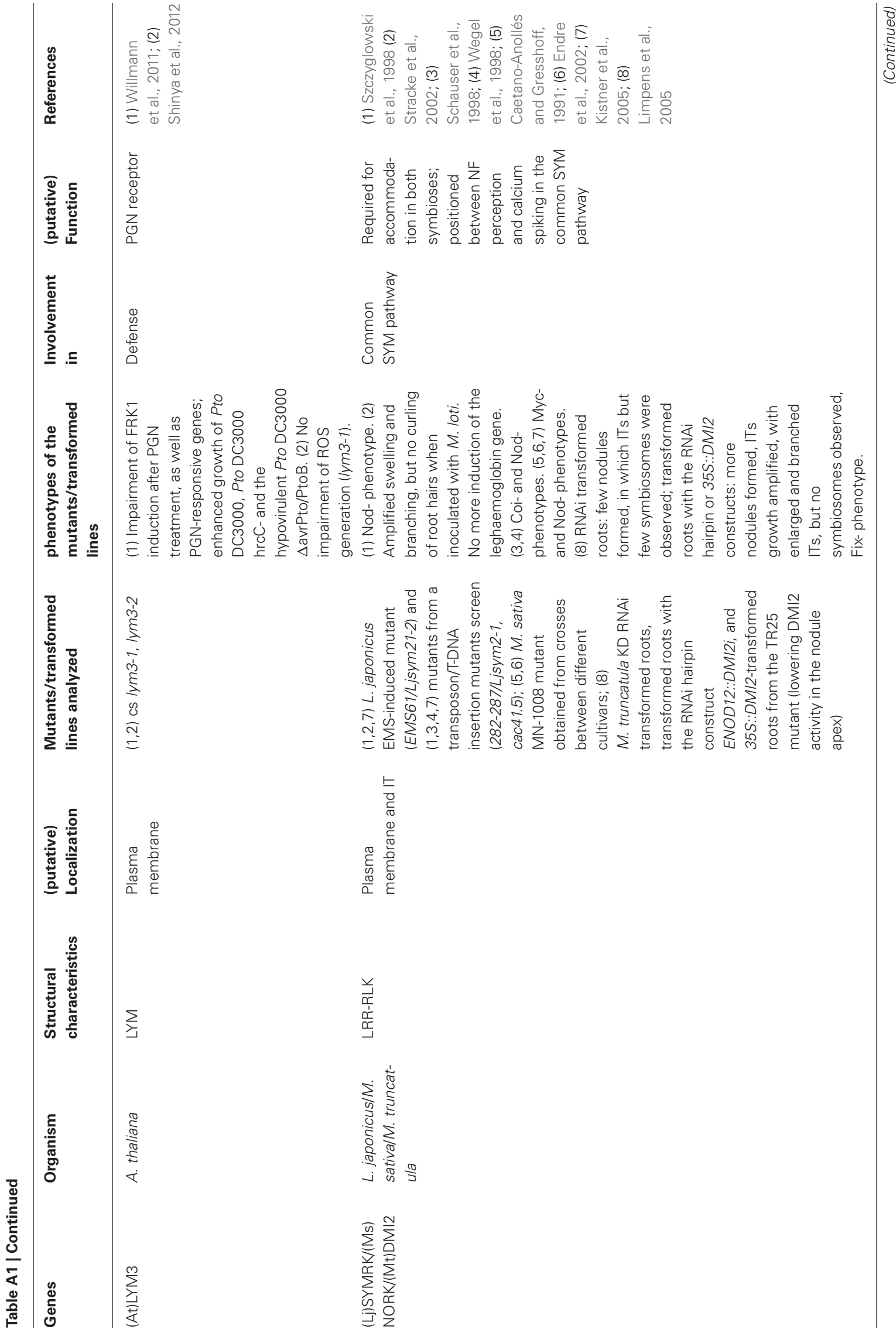




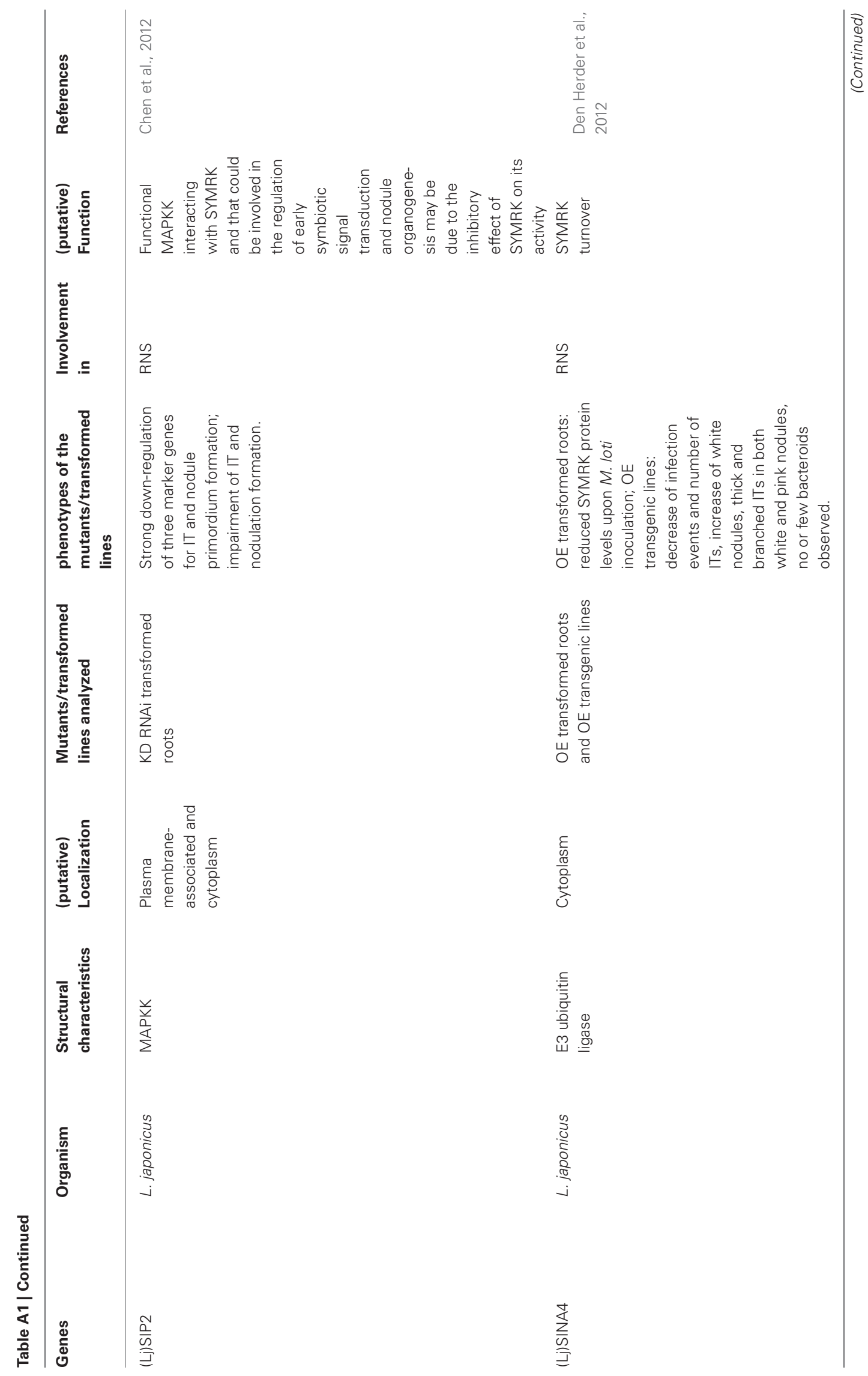




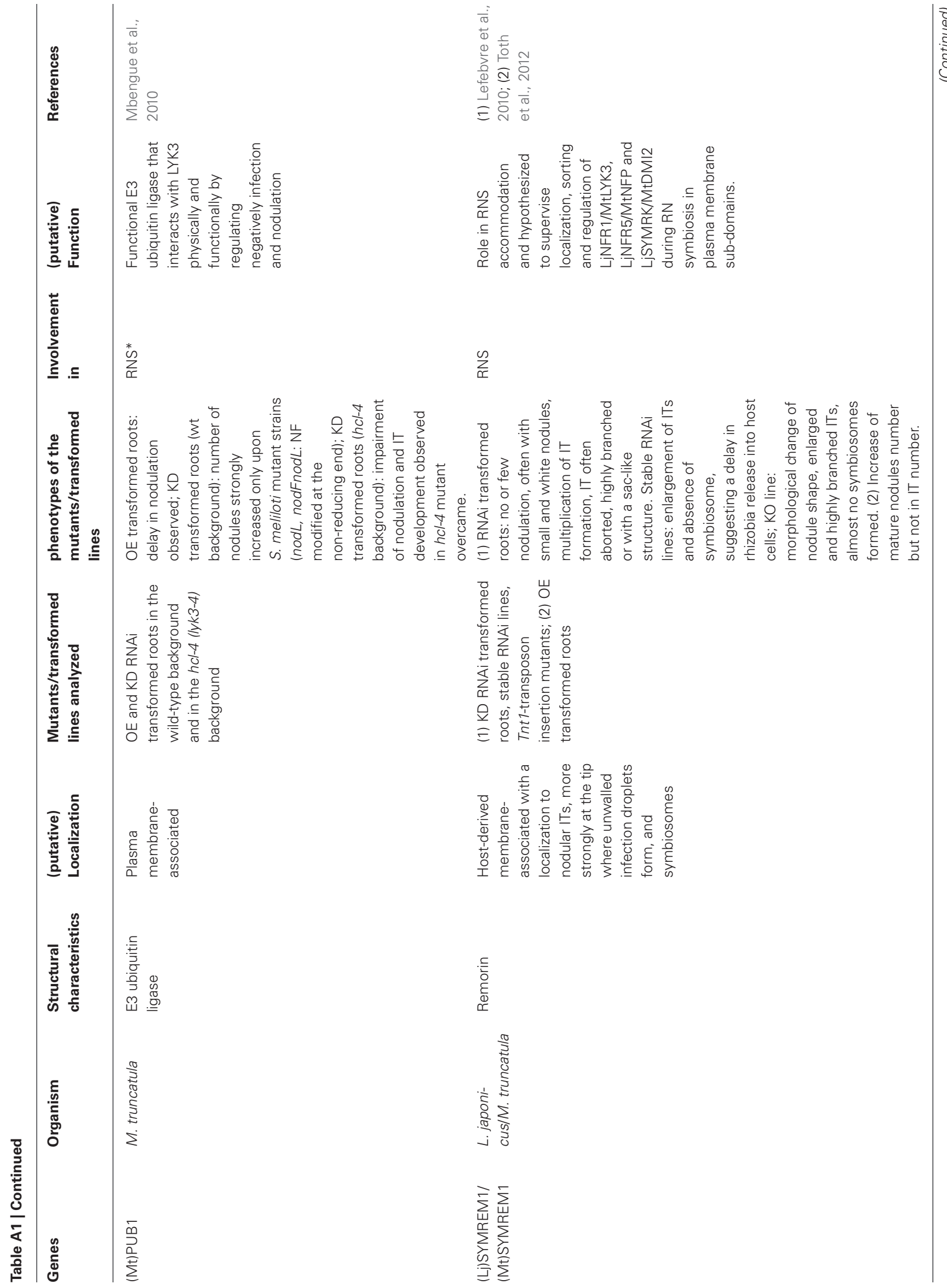




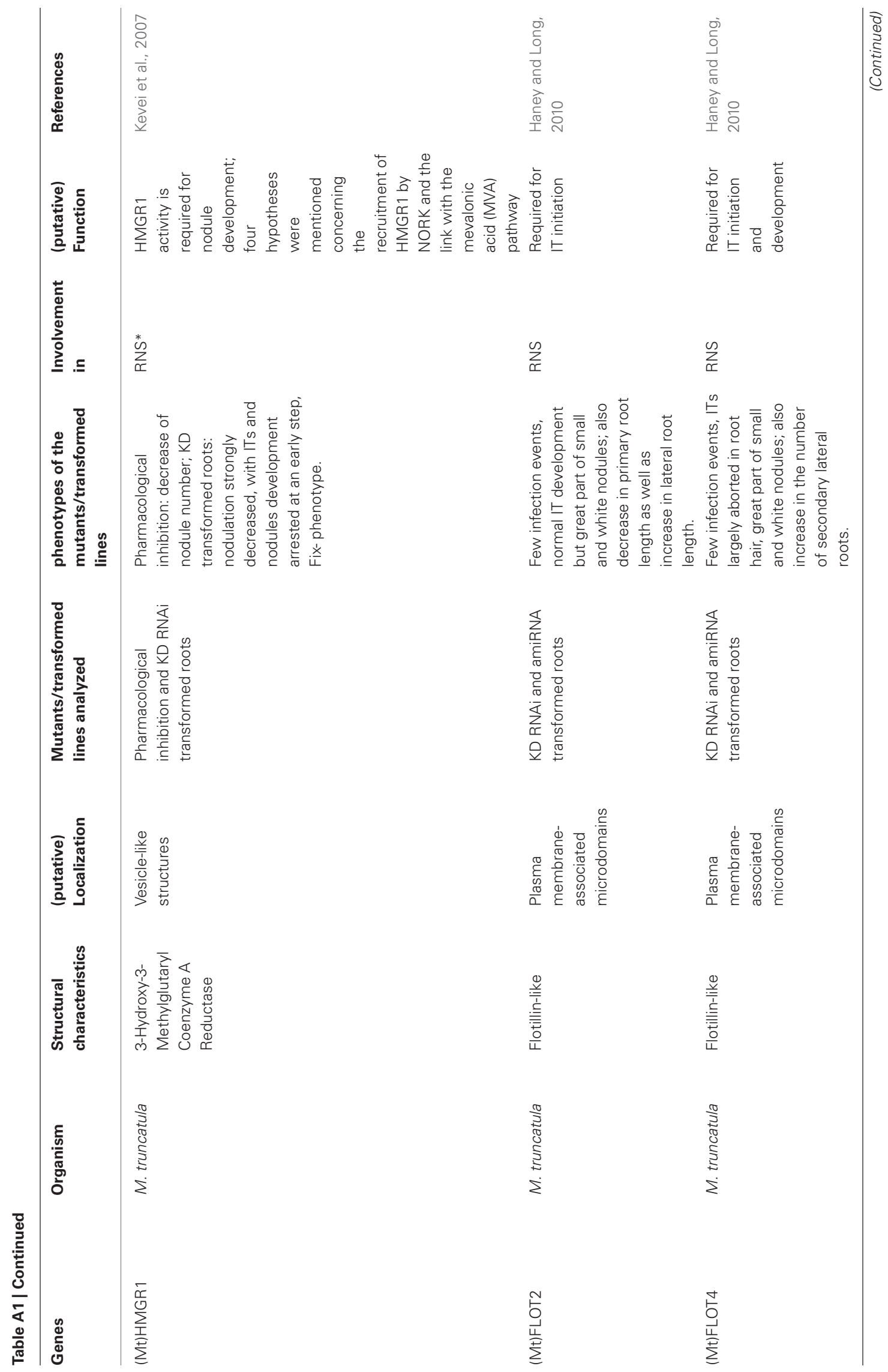




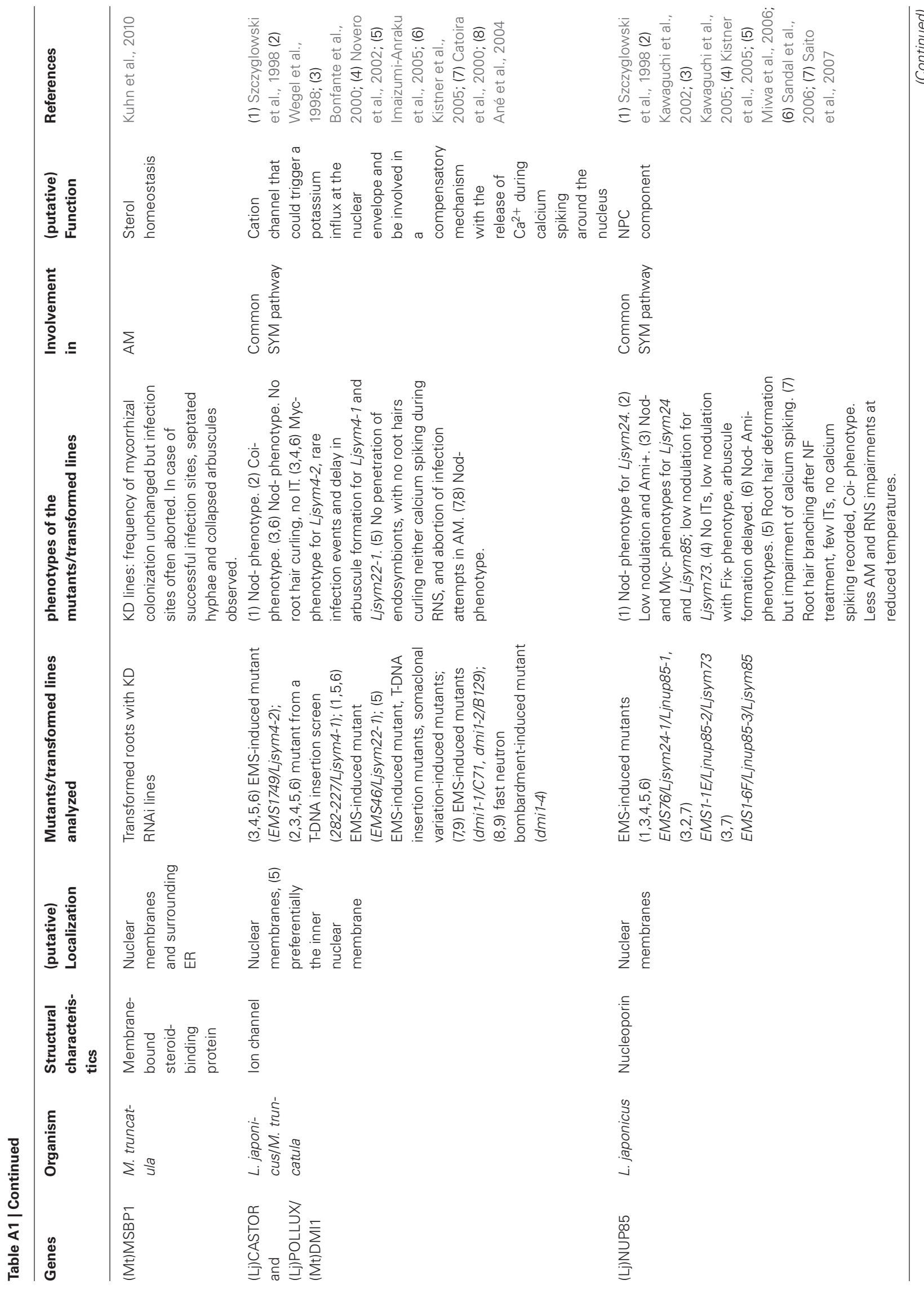




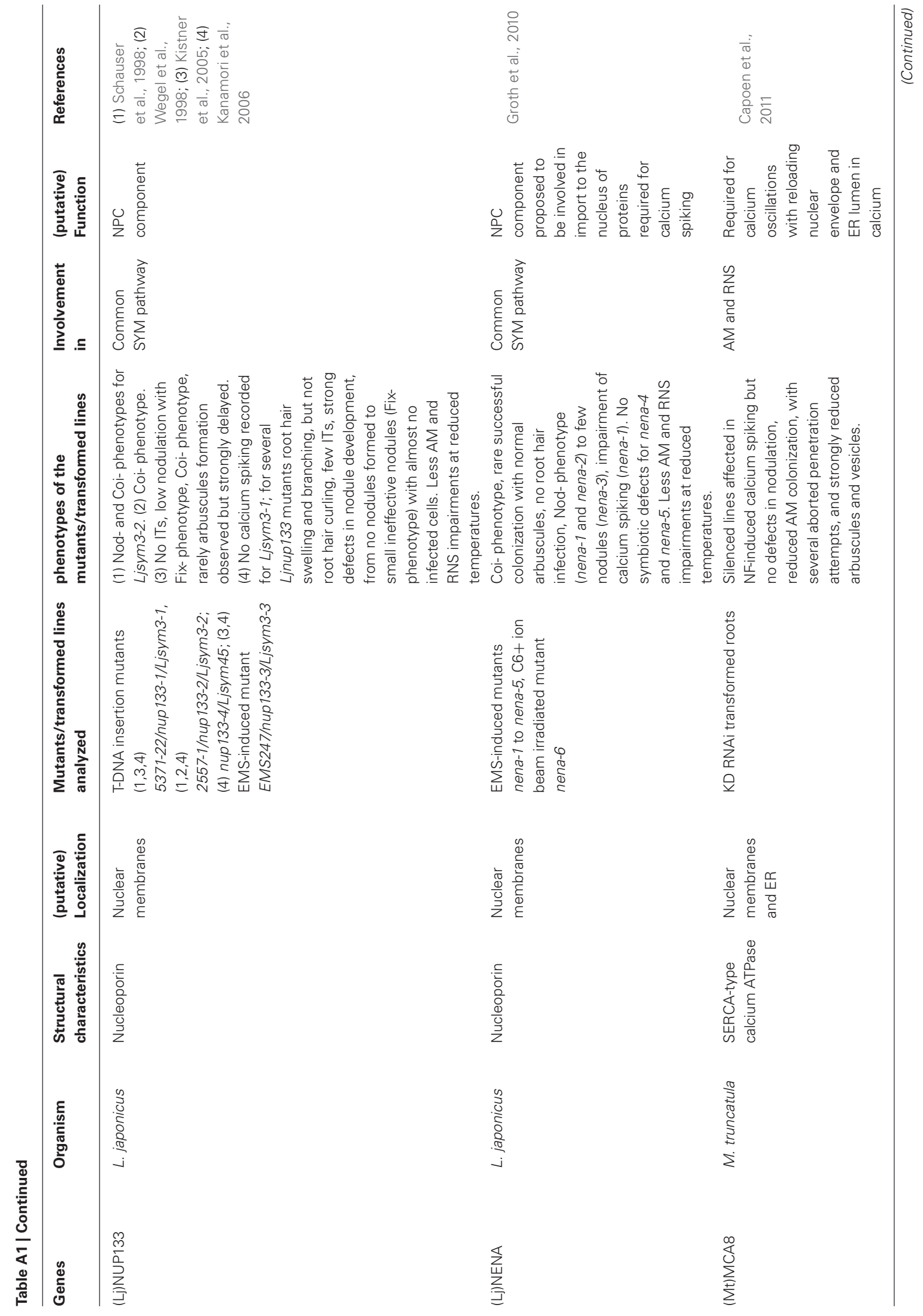




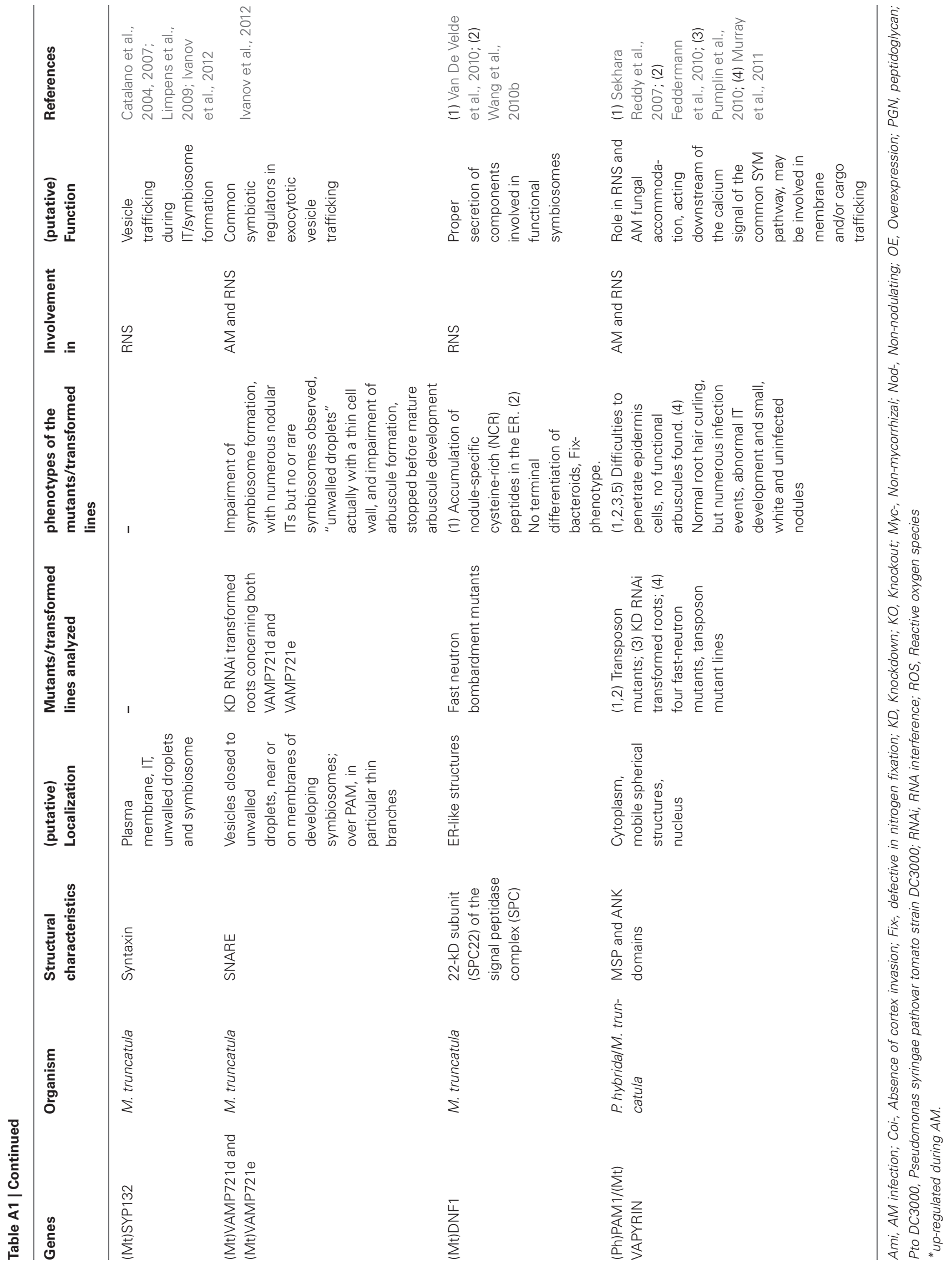




\section{REFERENCES}

Ané, J.-M., Kiss, G. B., Riely, B. K., Penmetsa, R. V., Oldroyd, G. E. D., Ayax, C., et al. (2004). Medicago truncatula DMI1 required for bacterial and fungal symbioses in legumes. Science 303, 1364-1367.

Bonfante, P., Genre, A., Faccio, A., Martini, I., Schauser, L., Stougaard, J., et al. (2000). The Lotus japonicus LjSym4 gene is required for the successful symbiotic infection of root epidermal cells. Mol. Plant Microbe Interact. 13, 1109-1120.

Caetano-Anollés, G., and Gresshoff, P. M. (1991). Efficiency of nodule initiation and autoregulatory responses in a supernodulating soybean mutant. Appl. Environ. Microbiol. 57, 2205-2210.

Catoira, R., Galera, C., De Billy, F., Penmetsa, R. V., Journet, E. P., Maillet, F., et al. (2000). Four genes of Medicago truncatula controlling components of a nod factor transduction pathway. Plant Cell 12, 1647-1665.

Catoira, R., Timmers, A. C. J., Maillet, F., Galera, C., Penmetsa, R. V., Cook, D., et al. (2001). The HCL gene of Medicago truncatula controls Rhizobium-induced root hair curling. Development 128, 1507-1518.

Haag, A. F., Baloban, M., Sani, M., Kerscher, B., Pierre, O., Farkas, A., et al. (2011). Protection of Sinorhizobium against host cysteine-rich antimicrobial peptides is critical for symbiosis. PLoS Biol. 9:e1001169. doi: 10.1371/journal. pbio. 1001169

Haney, C. H., and Long, S. R. (2010). Plant flotillins are required for infection by nitrogen-fixing bacteria. Proc. Natl. Acad. Sci. U.S.A. 107, 478-483.

Imaizumi-Anraku, H., Takeda, N., Charpentier, M., Perry, J., Miwa, H., Umehara, Y., et al. (2005). Plastid proteins crucial for symbiotic fungal and bacterial entry into plant roots. Nature 433, 527-531.

Karandashov, V., Nagy, R., Wegmuller, S., Amrhein, N., and Bucher, M. (2004). Evolutionary conservation of a phosphate transporter in the arbuscular mycorrhizal symbiosis. Proc. Natl. Acad. Sci. 101, 6285-6290.

Kawaguchi, M., Imaizumi-Anraku, H., Koiwa, H., Niwa, S., Ikuta, A., Syono, K., et al. (2002). Root, root hair, and symbiotic mutants of the model legume Lotus japonicus. Mol. Plant Microbe Interact. 15, 17-26.

Kawaguchi, M., Pedrosa-Harand, A., Yano, K., Hayashi, M., Murooka, Y., Saito, K., et al. (2005). Lotus burttii takes a position of the third corner in the Lotus molecular genetics triangle. DNA Res. 12, 69-77.

Kistner, C., Winzer, T., Pitzschke, A., Mulder, L., Sato, S., Kaneko, T., et al. (2005). Seven Lotus japonicus genes required for transcriptional reprogramming of the root during fungal and bacterial symbiosis. Plant Cell 17, 2217-2229.

Limpens, E., Franken, C., Smit, P., Willemse, J., Bisseling, T., and Geurts, R. (2003). LysM domain receptor kinases regulating rhizobial Nod factor-induced infection. Science 302, 630-633.

Mergaert, P., Uchiumi, T., Alunni, B., Evanno, G., Cheron, A., Catrice, O., et al. (2006). Eukaryotic control on bacterial cell cycle and differentiation in the Rhizobium-legume symbiosis. Proc. Natl. Acad. Sci. U.S.A. 103, 5230-5235.

Miwa, H., Sun, J., Oldroyd, G. E. D., and Downie, J. A. (2006). Analysis of nod-factor-induced calcium signaling in root hairs of symbiotically defective mutants of Lotus japonicus. Mol. Plant Microbe Interact. 19, 914-923.

Novero, M., Faccio, A., Genre, A., Stougaard, J., Webb, K. J., Mulder, L., et al. (2002). Dual requirement of the LjSym4 gene for mycorrhizal development in epidermal and cortical cells of Lotus japonicus roots. New Phytol. 154, 741-749.

Riely, B. K., Lougnon, G., Ané, J. M., and Cook, D. R. (2007). The symbiotic ion channel homolog DMI1 is localized in the nuclear membrane of Medicago truncatula roots. Plant J. 49, 208-216.

Sandal, N., Petersen, T. R., Murray, J., Umehara, Y., Karas, B., Yano, K., et al. (2006). Genetics of symbiosis in Lotus japonicus: recombinant inbred lines, comparative genetic maps, and map position of 35 symbiotic loci. Mol. Plant Microbe Interact. 19, 80-91.

Schauser, L., Handberg, K., Sandal, N., Stiller, J., Thykjaer, T., Pajuelo, E., et al. (1998). Symbiotic mutants deficient in nodule establishment identified after T-DNA transformation of Lotus japonicus. Mol. Gen. Genet. 259, 414-423.

Szczyglowski, K., Shaw, R. S., Wopereis, J., Copeland, S., Hamburger, D., Kasiborski, B., et al. (1998). Nodule organogenesis and symbiotic mutants of the model legume Lotus japonicus. Mol. Plant Microbe Interact. 11, 684-697.

Wegel, E., Schauser, L., Sandal, N., Stougaard, J., and Parniske, M. (1998). Mycorrhiza mutants of Lotus japonicus define genetically independent steps during symbiotic infection. Mol. Plant Microbe Interact. 11, 933-936. 